Fall 12-2-2020

\title{
Reducing Patient Falls by Realigning Nursing Hours per Patient Days
}

\author{
Hermes Vargas \\ University of St. Augustine for Health Sciences, h.vargas@usa.edu
}

DOI: https://doi.org/10.46409/sr.VXQF2417



This work is licensed under a Creative Commons Attribution 4.0 License.

Follow this and additional works at: https://soar.usa.edu/scholprojects

Part of the Health and Medical Administration Commons, and the Nursing Administration Commons

\section{Recommended Citation}

Vargas, H. (2020). Reducing Patient Falls by Realigning Nursing Hours per Patient Days. [Doctoral project, University of St Augustine for Health Sciences]. SOAR @ USA: Student Scholarly Projects Collection.

https://doi.org/10.46409/sr.VXQF2417

This Scholarly Project is brought to you for free and open access by the Student Research at SOAR @ USA. It has been accepted for inclusion in Student Scholarly Projects by an authorized administrator of SOAR @ USA. For more information, please contact soar@usa.edu, erobinson@usa.edu. 


\title{
Reducing Patient Falls by Realigning Nursing Hours per Patient Days
}

\author{
Hermes O. Vargas, MSN, MBA, RN, NEA-BC, CCRN-K, CNL, CMC
}

University of St. Augustine for Health Sciences for Health Sciences

This Manuscript Partially Fulfills the Requirements for the

Doctor of Nursing Practice Program and is Approved by:

Kathleen Farrell, DNSc, RN

Phyllis Dolin, DNP, RN-BC, CVRN

December 06, 2020 


\section{University of St Augustine for Health Sciences \\ DNP Scholarly Project \\ Signature Form}

\begin{tabular}{|l|l|l}
\hline $\begin{array}{l}\text { Studont Lact Hame: } \\
\text { Vargas }\end{array}$ & $\begin{array}{l}\text { Firat Hame: } \\
\text { Hemmes }\end{array}$ & 0 \\
\hline
\end{tabular}

\begin{tabular}{|c|c|c|}
\hline $\begin{array}{l}\text { E-mall: } \\
\text { h.vargas@usa.ed }\end{array}$ & mes.vargas@va.gov & \\
\hline Tithe of DNP Projent: & & \\
\hline Reducing Patient Fall & aligning Nursing Hours per Pati & nt Days \\
\hline 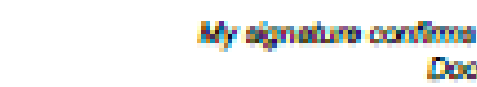 & 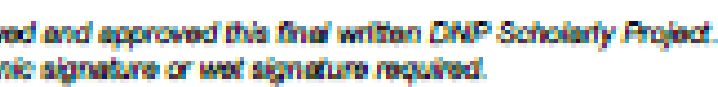 & \\
\hline Type Name in Blue Box Belowe & Blpnature & Date \\
\hline $\begin{array}{l}\text { DNP Project Primary Faculty. } \\
\text { Kathleen Farrell }\end{array}$ & $K_{\alpha t h u n}$ Fund & $11 / 24 / 20$ \\
\hline $\begin{array}{l}\text { DNNP Project Preceptor. } \\
\text { Phyllis Dolin }\end{array}$ & 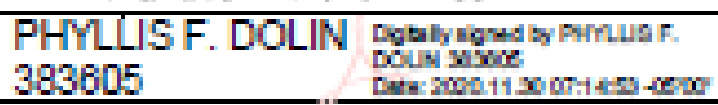 & $11 / 24 / 20$ \\
\hline DNP Project Preceptor: & & \\
\hline
\end{tabular}




\begin{abstract}
Patient falls are the "second leading cause of unintentional injury death" (World Health Organization [WHO] (2018), para. 3) and increase healthcare costs by an estimated \$13,806 per fall (Walsh et al., 2018). These fall-related costs translate to a potential savings of approximately $\$ 400,374$ to the selected organization since the unit chosen for the practice change project experienced 29 falls in the fiscal year 2019 (C. Hernandez, personal communication, September 23, 2019). The PICOT question that guided this project was: In a medical/surgical inpatient population in acute care (P) how does realigning the Nursing Hours per Patient Days (NHPPD) (I) compared to the patient population in medical/surgical units without an adjusted NHPPD (C) affect the fall rate $(\mathrm{O})$ within 60 days $(\mathrm{T})$ ? The literature search returned ten studies that matched the inclusion and exclusion criteria, promoting NHPPD to prevent patient falls in inpatient, acute care, medical/surgical hospital settings. The evidence-based intervention was a realignment of the approved and budgeted 9.4 NHPPD. The realignment was completed to increase the direct care nursing hours to meet the patient care demands during the 4-hour intervals with the highest reported falls (Taylor et al., 2015). The rate of falls observed between 1600-2000, the period evaluated, was 0 since no falls were reported during this project's duration. However, even though the $t$-test calculation returned a $p$-value $\leq 0.05$, the statistical significance was rejected since the correlation coefficient calculation between NHPPD and falls showed a weak relationship. Since there were no falls reported during the period evaluated, the clinical significance was established and correlated with the literature review evidence.
\end{abstract}




\section{Reducing Patient Falls by Realigning Nursing Hours per Patient Days}

Patient falls are detrimental not only as it relates to a patient's safety and quality of life, but it also adds unnecessary costs to our already burdened healthcare system. According to the Centers for Disease Control and Prevention [CDC] (2017), medical costs associated with falls exceed $\$ 50$ billion per year. Additionally, if the current trends continue, the CDC (2017) projects that by 2030 there will be seven fall-related deaths every hour. This paper discusses an evidencebased practice (EBP) change in a medical/surgical acute care unit. The project aimed to reduce the fall rate by realigning the Nursing Hours per Patient Days (NHPPD).

\section{Significance of the Practice Problem}

Patients who experience a fall are affected by the potential physical injury and experience fear, anxiety, and depression. This experience can result in "social isolation, and feelings of helplessness" (National Council on Aging [NCOA], n.d., para. 3). Families and caregivers are also affected and often encounter similar psychological, emotional, financial, and social manifestations that compromise their quality of life (Golics et al., 2013). The economic impact associated with patient falls is substantial and presents opportunities for organizations to consider fall prevention.

In adult medical-surgical units in the United States, patients fall at a rate of "3.56 times per 1,000 patient days, with $26.1 \%$ of falls resulting in patient injuries" (Walsh et al., 2018, p. 75). Additionally, falls with injuries add 6.9 days to their hospital length of stay (LOS) and increases the cost by $\$ 13,806$ per fall with injuries (Walsh et al., 2018). The reported cost per fall translates to a potential savings of approximately $\$ 400,374$ to the selected organization since the unit chosen for the practice change experienced 29 falls in the fiscal year 2019 (C. Hernandez, personal communication, September 23, 2019). The national-level estimate is that approximately 
700,000 to $1,000,000$ patients fall in hospitals in the United States each year, adding a burden to the already stressed healthcare system (Ganz et al., 2013). Furthermore, the World Health Organization [WHO] (2018) cites that globally, falls are the "second leading cause of unintentional injury death" (para. 3). Therefore, a practice change that aims to reduce patient falls has the potential to impact the organization's finances, the patient's and family's quality of life, and patient and staff satisfaction.

\section{PICOT Question}

PICOT question: In a medical/surgical inpatient population in acute care $(\mathrm{P})$ how does realigning the NHPPD (I) compared to the patient population in medical/surgical units without an adjusted NHPPD (C) affect the fall rate (O) within 60 days $(\mathrm{T})$ ?

\section{Population}

This project's selected unit was an inpatient 27-bed medical/surgical unit in an acute care setting part of a quaternary medical center serving primarily geriatric patients (James A. Haley Veterans Hospital, 2017). The organization is a teaching hospital affiliated with the local School of Medicine and the School of Nursing, serving Veterans with over 200,000 visits per year (James A. Haley, 2017).

\section{Intervention}

The intervention was a realignment of the approved and budgeted 9.4 NHPPD in the selected Inpatient Acute Care Medical/Surgical unit. The realignment was completed to increase the direct care nursing hours to meet the demands during the 4-hour intervals with the highest reported falls (Taylor et al., 2015). The NHPPD realignment was made with input from the unit's Nurse Manager to consider other initiatives and directives and to ensure staff support during the project (Vargas, 2019). The fall rate, obtained from the patient safety team's existing reports, 
identified falls through electronic health records documentation correlated with daily nursing operations reports.

\section{Comparison Population}

The Fiscal Year 2019 fall rate in the acute care hospital where the project was implemented was 3.4/1000 patient-days (C. Hernandez, personal communication, September 23, 2019). While this organization's fall rate is below the national rate, the medical/surgical inpatient acute care unit where the intervention was implemented is $3.76 / 1000$ patient-days. This rate is slightly above the national standards identified in the literature and represented an opportunity to reduce costs, improve patient care, and enhance patient and staff satisfaction.

The original plan was to compare the findings to a medical/surgical unit with similar fall rates in acute care. However, due to the global health impact associated with the Corona Virus (COVID-19) pandemic, the comparison was modified. Instead of using a comparison unit, the findings were compared to the prior year's data during the same period evaluated in the same unit where the intervention took place. The comparison period included the same fall prevention approach maintaining the same institutional policies and procedures.

\section{Outcome}

The anticipated outcome was to decrease the fall rate by $5 \%$ each month from the existing 3.76/1000 patient-days. The goal was to reach 3.4/1000 patient-days or lower, the average fall rate in acute care at this facility. The fall rate was calculated as the number of falls divided by the number of occupied bed days for the month multiplied by 1000 . This calculation returned the rate of falls per 1,000 occupied bed days. The calculation is a validated formula established by the National Database of Nursing Quality Indicators (NDNQI) presented by the Agency for Healthcare Research and Quality [AHRQ] (2013). The established organizational 
reports and NHPPD tools were used to compare pre- and post-intervention rates using the nursing operations NHPPD data (Vargas, 2019). Additionally, the raw number of falls was obtained from the daily charge nurse and nursing operations reports to compare pre- and postintervention outcomes. The number of falls allowed the project team to consider the clinical significance since the statistical significance was not established due to the limited project timeline and unit access restrictions.

\section{Timing}

According to Ganz et al. (2013), the recommendation was to collect the data each month to provide more opportunities to give staff feedback about improvements. Obtaining and reviewing the data each day and aggregating it each month maximized the ability to make the necessary changes to complete the evaluation within the 60 days set to finalize the project. The monthly audits with stakeholder feedback helped refine the intervention. Continuous communication further promoted the chance to prevent falls by optimizing staffing using the realigned NHPPD benchmarks, thereby decreasing the fall rate in the unit evaluated.

\section{Evidence-Based Practice Change Framework and Change Theory}

\section{Evidence-Based Framework}

According to D'Andreamatteo et al. (2015), organizations need to establish processes that promote efficiency and better patient outcomes. Strong leadership and methodology with employee participation are how organizations can establish these efficient processes.

Organizations can maximize efficiency and productivity by removing unnecessary steps. The efficiency is gained by combining steps duplicated by various departments and employing other lean concepts without compromising quality or safety (D’Andreamatteo et al., 2015). 
The quality and safety components associated with patient falls were aligned with the Institute for Healthcare Improvement's (IHI) Triple-Aim framework. This framework was developed to "address improving the patient experience of care (including quality and satisfaction); improving the health of populations; and reducing the per capita cost of health care" (Institute for Healthcare Improvement [IHI], n.d.a, para. 1). Therefore, since this practice change had the potential to affect the patient experience, improve health, and reduce costs, the Triple-Aim framework aligned well with this EBP project.

\section{Change Theory}

Lippitt's theory of change was used to guide the EBP project to evaluate how NHPPD can promote better patient outcomes. Lippitt's theory of change is an extension of Lewin's threestep theory that dominated organizational change from the 1950s through the 1980s (Spear, 2016). This theory includes “1) problem diagnosis, 2) motivation to change assessment, 3) change agent's motivation to change, 4) change determination, 5) roles of the change agent(s), 6) change maintenance, and 7) termination" (Stoeckle et al., 2018, table 3).

Alligood (2014) identifies five criteria to facilitate the analysis of theoretical works "1) clarity, 2) simplicity, 3) generality, 4) accessibility, and 5) importance” (box 1-3). These five criteria were addressed by Mitchell (2013), who associates Lippitt's change theory with the nursing process. Mitchell (2013) reports that the seven phases in Lippitt's theory apply similar language used in the nursing process, allowing nurses to use a model already familiar to their

discipline. This familiarity provides a simple process that nurses can use to guide their practice to ensure sustainable implementation of the applicable findings. The nursing process' similarities promoted stakeholder acceptance, thereby increasing the project's success and sustainability (Vargas, 2018). 


\section{Evidence Search Strategy}

The Cumulative Index to Nursing and Allied Health Literature (CINAHL) database and the PubMed database were searched to review the literature supporting this practice change project's PICOT question. The digital search was completed combining the keywords fall, patient, and hospital, limiting the search to peer-reviewed articles published in English from 2015 through 2020. The search was further limited by applying the phrase nursing and staffing since these were the specific concepts reviewed in this project. Articles outside of a medical/surgical acute care inpatient setting were excluded to consider only the population evaluated in this project. The duplicate reports between the databases searched were identified and removed from the final list of articles deemed to be eligible for assessment. Using the Johns Hopkins Nursing Evidence-Based Practice (EBP) evidence level and quality guide, the studies were evaluated (Dang \& Dearholt, 2017). This evaluation resulted in studies ranging from a level of evidence of II-III and a quality grade of B-C (see Appendices A and B).

\section{Evidence Search Results and Evaluation}

The initial search using the keywords fall, patient, and hospital limited to peer-reviewed articles published in English between 2015-2020 returned 1,828 articles in CINAHL and 4,465 articles in PubMed. After applying the keywords nursing and staffing, the CINAHL search returned 43 articles, and the one in PubMed returned 32 articles. These terms were used because they were the concepts associated with the intervention evaluated in this project. Sixteen of the 32 articles from the PubMed search were duplicate articles included in the CINAHL database search. Two of the remaining 59 articles were excluded because they were research protocols and not completed studies. Of the remaining 57 articles, 47 were excluded because it introduced modalities that are 1) not within the scope of this project, 2) did not discuss the relationship to 
patient falls, or 3) were not conducted in a medical-surgical acute care inpatient setting. The remaining ten studies included eight quantitative studies and two systematic reviews (see Figure 1 for Prisma flow diagram summary).

The evidence's strength was rated using the Johns Hopkins Nursing Evidence-Based Practice (EBP) evidence level and quality guide (Dang \& Dearholt, 2017). The individual studies evaluated ranged from evidence Level II-III and a B-C quality grade. Only one study was rated a Level III due to its non-experimental design. Two studies were rated C, one due to the small, limited falls data collected, and the other due to the low level of evidence and inconclusive results (see Appendix A).

The two systematic reviews were rated IIB using the same tool used to grade the individual studies (see Appendix B). The first systematic review included 29 studies that examined associations between work environment and nurse-sensitive patient outcomes in hospitals. The studies also included patient falls, using a quantitative study design, written in English, and published from 2004 to 2012. The 29 studies reviewed included 17 cross-sectional retrospective studies, one longitudinal cohort study, seven longitudinal cohort retrospective studies, two longitudinal cohort prospective studies, one retrospective study, and one randomized controlled trial (Stalpers et al., 2015).

The second systematic review evaluated 14 studies that were selected using nurse staffing measures, published in peer-reviewed journals, available in the English language as its inclusion criteria. The study designs listed in their systematic review included six cross-sectional studies, one cross-sectional correlational study, four correlational studies, two longitudinal studies, and one retrospective study (Amin \& Scott, 2016). Even though this systematic review did not 
specifically evaluate patient falls, it provided a basis for establishing the validity and reliability of NHPPD and its relationship to the quality of patient care delivered (Amin \& Scott, 2016).

\section{Themes from the Evidence}

The topic of nurse staffing and its effect on patient outcomes was well documented. However, establishing a cause and effect was difficult because the samples were complex due to multiple variables. These factors included nurse staffing, the type of organization, its resources, mission, and values. The literature review conducted to answer the PICOT question for this project resulted in 3 key themes: 1) skill mix, 2) work environment, and 3) NHPPD/ratios (see Figure 2). All the studies evaluated used a rate of fall per 1000 patient days as described by the National Database of Nursing Quality Indicators (Everhart et al., 2014).

\section{Skill Mix}

Skill mix relates to the proportion of Registered Nurses (RN) compared to Licensed Practical Nurse (LPN), Nursing Assistant (NA), and other unlicensed assistive personnel (UAP). Six studies identified the skill mix in their discussion. The studies showed considerable variability in their findings. Four studies were rated IIB; one was rated IIC due to its inconsistent result; one study was rated level IIIC due to its non-experimental design and inconsistent results (see Appendix A).

Three IIB studies concluded that there was an inverse association between RN skill mix and patient falls (Cox et al., 2015; He et al., 2016; Kim et al., 2019). One study, rated IIC, suggested "higher rates of skill mix were related to total patient falls" but did not identify the specific skill mix rate (Koualty et al., 2018, p. 357). Two studies identified skill mix as one of the variables included in their definition of unit characteristics. However, the studies did not present data indicating that the individual types of nursing staff were evaluated (Staggs et al., 
2015; Zadvinskis et al., 2019). Although the fall rate results related to skill mix were inconclusive, this theme was evaluated for consistency with the percentage approved during the unit's yearly staffing methodology review.

\section{Work Environment}

The work environment was discussed in three studies rated IIB and one systematic review rated IIB. The studies identified conditions, such as hospital and unit characteristics, professional models of care, and leadership support among the factors that may influence patient outcomes (Baernholdt et al., 2018; Cho et al., 2016; Staggs et al., 2015; Stalpers et al., 2015). Staggs et al. (2015) reviewed characteristics that provided a low or high-fall unit classification. The study suggested that patient days was a statistically significant factor associated with a high fall classification and should be considered when developing fall prevention strategies. All the studies that evaluated the work environment suggested organizations consider 1) staff education level, 2) experience, and 3) other work environment factors to have an impact on preventable nursing-sensitive outcomes like patient falls (Baernholdt et al., 2018; Cho et al., 2016; Staggs et al., 2015; Stalpers et al., 2015).

\section{Nursing Hour per Patient Day (NHPPD)/Staffing Ratio}

All the studies reviewed addressed the NHPPD theme. Nursing HPPD realignment was the intervention evaluated in this project. The studies were assessed based on the effect of NHPPD on patient falls, an outcome identified in the PICOT question.

Two studies did not demonstrate a statistically significant relationship between NHPPD/staffing and falls. One of the two systematic reviews with a IIB level of evidence rating established high predictive reliability of NHPPD for patient falls. The review suggested adjustments in the measure's application were necessary to capture patient, staff, and 
organizational characteristic variations (Amin \& Scott, 2016). The second systematic review, also rated a IIB level of evidence, evaluated several high-quality studies that reported inverse effects between staffing and falls (Stalpers et al., 2015). Four IIB rated studies and one IIC study reported statistically significant inverse relationships between falls and NHPPD/staffing (see Appendix A).

Additionally, Kim et al. (2019) reported increasing NHPPD by one hour decreased falls by $67 \%$. Cho et al. (2016) suggested that one additional NHPPD decreased fall rates by $8 \%$ or $10 \%$ if the hour was associated with RN care. In contrast, Staggs et al. (2015) indicated they found little difference in staffing between units with persistently high or low rates. Out of the ten studies included in the review, six IIB studies and one IIC study showed favorable statistically significant associations to address this project's PICOT question (see Appendices A and B).

\section{Practice Recommendations}

The recommended change was to realign the NHPPD to increase direct care hours during periods of high turbulence when the unit evaluated reported a higher number of falls. NHPPD was selected over the other two themes because realignment is an operationally feasible factor at the discretion of the unit's manager and nursing service director. In contrast, changes to the unit's skill mix would require budgetary adjustments that are only considered during the facility's annual staffing methodology review. Likewise, the work environment theme included components, such as staff education level, certifications, and other factors, which are conditions that cannot be readily adjusted during this project (Baernholdt et al., 2018; Cho et al., 2016; Cox et al., 2015; He et al., 2016; Kim et al., 2019; Staggs et al., 2015; Stalpers et al., 2015; Zadvinskis et al., 2019). 
The body of evidence reviewed is rated IIB with only one study rated IIC due to its inconsistent result, and another study rated IIIC due to its non-experimental design and inconsistent results (see Appendices A and B). Six studies reported an inverse relationship between NHPPD and patient falls and supported the NHPPD realignment intervention for this project (Baernholdt et al., 2018; Cho et al., 2016; Cox et al., 2015; He et al., 2016; Kim et al., 2019; Koualty et al., 2018). Likewise, the two systematic reviews, both rated IIB, reported inverse effects between staffing and falls (Amin \& Scott, 2016; Stalpers et al., 2015). Out of the ten studies included in the review, seven IIB studies and one IIC study showed favorable statistically-significant associations to address the PICOT question for this project (Amin \& Scott, 2016; Baernholdt et al., 2018; Cho et al., 2016; Cox et al., 2015; He et al., 2016; Kim et al., 2019; Koualty et al., 2018; Stalpers et al., 2015). The findings reported in these high-quality studies provided a high degree of confidence, suggesting that realigning the NHPPD during periods when falls occur most frequently in this unit would decrease their fall rate.

\section{Project Setting}

\section{Description}

The selected unit was an inpatient 27-bed medical/surgical ward in an acute care setting in a quaternary medical center with a 415-bed capacity. The medical center is considered one of the largest integrated medical facilities in the United States. This organization serves primarily geriatric patients in the Tampa area with clinics in Lecanto, Brooksville, New Port Richey, Zephyrhills, Lakeland, Temple Terrace, and Riverview (James A. Haley, 2017). The organization is a teaching hospital affiliated with the local School of Medicine and the School of Nursing, serving Veterans with over 200,000 visits per year (James A. Haley, 2017). 


\section{Organizational Culture}

An organizational assessment was completed using the Checklist to Assess Organizational Readiness (CARI) and the Institute for Healthcare Improvement (IHI) Improvement Capability Self-Assessment tools. In addition to these organizational readiness tools, a Harvard Business Review survey was completed to assess the organization's culture. The information collected using these tools described an organization with the infrastructure, resources, leadership, staff engagement, competence, and capability to support process improvement initiatives (Vargas, 2019). The tools also revealed the organization's highly bureaucratic process, a characteristic considered during the project's planning phase. Furthermore, using the cultural profile survey by Groysberg et al. (2018) revealed an organization driven by results and learning.

\section{Organizational Structure}

The site was a medical center part of the largest integrated health care system in the United States, collectively providing care to over "9 million patients in 170 medical centers and 1,074 outpatient sites" (U.S. Department of Veterans Affairs, n.d.a, para. 1). The healthcare system was divided into 19 Networks across the country designed to provide geographical coverage to serve the population at the local level. The project site was part of the network that provides health care services to patients in Florida, South Georgia, Puerto Rico, and the U.S. Virgin Islands (U.S. Department of Veterans Affairs, n.d.c). The facility is led by a Medical Center Director who serves as the Chief Executive Officer with a governance council that includes a Resource Management board, Clinical Executive board, Quality, Safety, Value (QSV) board, and Patient Care Executive board. The executive leadership team was referred to as the Pentad since it consists of five members: Director, Deputy Director, Chief of Staff, Associate 
Director, Associate Director Patient Care/Nursing Services, and Assistant Director. Each Pentad member oversaw different service lines led by Chiefs with mid-level managers assigned to the sections under their respective responsibility areas.

The organizational structure transformed in 2015 from a reactive, physician-centered care approach to a proactive, interdisciplinary care approach with the patient's values and goals driving the healthcare relationship based on core values associated with "Integrity, Commitment, Advocacy, Respect, and Excellence" coined the ICARE model (U.S. Department of Veterans Affairs, n.d.b, para. 3). This transformation developed a culture where process improvement initiatives are highly supported, and Just Culture concepts associated with high-reliability organizations (HRO) were integrated to promote a safer patient care environment (Boysen, 2013).

\section{Organizational Needs}

This unit was selected based on feedback from the Falls Prevention Committee chairperson who identified the medical-surgical unit as experiencing the highest fall rate in the acute care service (C. Hernandez, personal communication, September 23, 2019). The organizational needs were identified by completing a strengths, weaknesses, opportunities, and threats (SWOT) analysis in consultation with the organization's Falls Prevention Committee and the acute care nursing leadership team. The SWOT analysis revealed strong teamwork, interdisciplinary collaboration, commitment to process improvement, low turnover rate, and adoption of evidence-based practices. The analysis also identified weaknesses and opportunities related to staffing, operational processes, turbulence, and NHPPD education (see Figure 3 for complete SWOT analysis). 


\section{Stakeholders}

The stakeholders identified for this project included the Nurse Executive as the project sponsor, the Nursing Acute Care and Nursing Operations Chief Nurses as the co-champions, the Unit Nurse Manager and staff as the clinical stakeholders, and the patients served and their families. The Falls Prevention Committee Chairperson served as a consultant to review the ongoing falls-related data.

\section{Organizational Support}

There were recent directives to increase efficiency and performance to promote better outcomes and better customer experience. These efforts were supported by a robust culture of continuous process improvement with dedicated staff who are Lean Six Sigma Master Black Belt certified. This systems redesign team is equipped to train staff about lean six sigma process methodology and serve as consultants on projects identified by the senior leadership. This high level of commitment to continuous process improvement through evidence-based practice changes is further promoted by the selected unit and Acute Care service nursing leadership team.

\section{Sustainability}

For initiatives to be successful, leaders need to incorporate strategies that promote support throughout the change continuum and ensure sustainability. The Agency for Healthcare Research and Quality (AHRQ) developed a Comprehensive Unit-Based Safety Program (CUSP) toolkit that guides leaders through a systematic process that includes:

- assemble the team

- $\quad$ engage the senior executive team for support

- understand the science of safety

- identify defects through sensemaking 
- implement teamwork and communication

- application

- role designation

- $\quad$ spread

- patient and family engagement

- $\quad$ setting SMART goals

(Agency for Healthcare Quality and Research [AHRQ], 2017a).

In addition to using this tool, the nursing operations leadership team was engaged from the project's inception to ensure continuity, support, sustainability, and dissemination. This involvement was necessary since the nursing operations service manages the patient flow center and is responsible for NHPPD related metrics.

\section{Interprofessional Collaboration}

Interprofessional collaboration is the relationship established by two or more disciplines working towards a common goal (Green \& Johnson, 2015). This relationship's effectiveness increases when the team follows a structured process that values individual contributions and is grounded in trust and confidence (Bosch \& Mansell, 2015). Another factor that supports engagement is role clarity. Role clarity helps prevent confusion and decreases the waste associated with duplication and overlap. It also allows team members to function to "their fullest potential" (Bittner, 2018, p. 345). Although this practice change is a function that is solely a nursing responsibility in this organization, there is collaboration with other disciplines related to the overall care of the patients in the selected unit. The fall-prevention roles include:

- Nurse - completes and documents fall risk assessments

- Nurse aide/health tech - assists with toileting and call bell response 
- Treating medical provider - reviews need for specific types of rehabilitation therapy, medications, interventions, and activity orders

- Pharmacist - medication reconciliation and identifies high risk for falls based on medication profile; makes recommendations for medication changes or dosing adjustments

- Physical or occupational therapist - provides skilled therapy to improve ambulation, transfers, bathing, and dressing; makes recommendations for assistive devices or adaptive equipment

\section{Project Overview}

\section{Project's Vision and Mission}

The organizational mission is to "Honor America's Veterans by providing exceptional health care that improves health \& well-being"; the vision is to "honor those we serve by providing 5-star primary to quaternary health care" (James A. Haley Veterans Hospital, n.d., para. 1). Since patient falls contribute to extended LOS, injuries, and decreased outcomes, this project aligned well with the organization's core values, founded on improving health, wellbeing, and providing safe, exceptional care.

\section{Objectives}

This evidence-based practice change project aimed to establish how realigning the NHPPD at every four-hour interval throughout the day can reduce the fall rate. The premise was to increase direct care hours during periods of high turbulence and a reported greater number of falls. The main objective was to reduce the fall rate by $5 \%$ from the previous month until it reached 3.4/1000 bed days or lower, the average rate in acute care (C. Hernandez, personal communication, September 23, 2019). This rate reduction was accomplished by setting a 
timeline with specific benchmarks, including specific tasks that were required throughout the project (see Appendix C). The long-term objective was to reach sustainability and to disseminate the practice throughout the organization and to other medical centers in the network.

\section{Risks and Unintended Consequences}

Other fall-risk prevention interventions were expected to improve as the Project Manager highlighted the purpose of this project change, thereby promoting a better fall-prevention outcome. Another positive unintended consequence was an increase in patient and staff satisfaction scores. According to AHRQ, there is a positive relationship between patient satisfaction scores and outcomes (Agency for Healthcare Research and Quality [AHRQ], 2017b). Consequently, better clinical outcomes and higher patient satisfaction scores can improve staff satisfaction.

The most significant expected barrier was the inability to support the NHPPD realignment due to organizational demands during the selected period. There was also a risk that other units would not receive the same level of attention by the nursing supervisors as they allocated resources to meet the project's NHPPD goal in the selected unit for this project. Additionally, there were operational changes and a lower occupancy rate due to the limitations required to support the conditions associated with the global COVID-19 pandemic.

\section{Project Plan (Method)}

The quality and safety components associated with patient falls were aligned with the Institute for Healthcare Improvement's (IHI) Triple-Aim framework. This framework was selected because it was developed to address patient safety, which is the main objective of this evidence-based practice change project (IHI, n.d.a). Additionally, Lippitt's theory of change was used as the model to guide this project. This theory includes "1) problem diagnosis, 2) 
motivation to change assessment, 3) change agent's motivation to change, 4) change determination, 5) roles of the change agent(s), 6) change maintenance, and 7) termination" (Stoeckle et al., 2018, table 3). Mitchell (2013) associated Lippitt's theory with the nursing process. He suggested that, since it was already a model familiar to their discipline, it provides a simple process that nurses can use throughout a project's life. Therefore, this familiarity promoted stakeholder acceptance, thereby increasing the project's success and sustainability (Vargas, 2018). Lippitt's theoretical concepts are described in the next section as associated by Mitchell (2013) using the nursing process elements (see Figure 4).

\section{Assessment}

Mitchell (2013) associated assessment with motivation to change assessment and change agent's motivation to change from Lippitt's theory. Assessment in the nursing process is described as the first step requiring critical thinking skills and data collection of subjective and objective information (American Nurses Association [ANA], n.d.). During this phase, the organizational needs assessment was completed, and the corporate and stakeholder support was assessed for readiness. A cursory discussion with the unit's nursing leadership and Falls Prevention chairperson established a need for this project. Once the project was approved through the required university and organizational EBP project approval process, a thorough review of the falls rate data was completed.

\section{Diagnosis}

Diagnosis refers to the clinical judgment about the "client's response to actual or potential health conditions or needs" (ANA, n.d., para. 3). This phase in Lippit's theory is referred to as Problem Diagnosis (Mitchell, 2013). This phase took place immediately after the university and the project site approved the project. After reviewing the fall data, the selected unit was assessed 
to consider workload, flow, staffing characteristics, and census to determine high turbulence periods to make adequate NHPPD realignment recommendations.

\section{Planning}

This section included two phases from Lippit's theory: change determination and roles of the change agent(s) (Mitchell, 2013). The planning period in the nursing process includes the steps required to develop actions towards the desired outcomes based on the diagnosis and assessment. During this phase, the project proposal was submitted for EBP approval using the appropriate university and project site process. Once officially approved, the project plan was introduced at the scheduled nursing leadership meeting to gain support.

The next steps included identifying project champions in collaboration with the unit nurse manager and Chief Nurses from Acute Care and Operations. After the project team selection, the Acute Care service nurse educator was enlisted to assist with the in-service to reach $80 \%$ of the staff before June 2020, the anticipated project start date. However, the acute care nursing leadership requested to omit the in-service to avoid staffing conflicts already disrupting operations related to the unit changes in place to support the COVID-19 pandemic. The rationale for not disclosing information about NHPPD realignments to the nursing staff was related to other initiatives occurring simultaneously to support the creation of temporary units dedicated to treating COVID-19 patients.

Although the NHPPD realignment was intended to be budget neutral, there were costs associated with training and in-services. The estimated costs associated with training 40 staff members in that unit and ten members from the nursing operations and education team was estimated at $\$ 1,650$. This calculation was obtained from data supplied by the facility's financial 
department (see Appendix D). However, we did not incur these costs since we omitted this step at the organization's nursing leadership request.

\section{Implementation}

Lippit's change maintenance is associated with the implementation step in the nursing process (Mitchell, 2013). During the implementation phase, the actions outlined in the plan were executed. For this project, the plan included the following steps:

- implemented the project in the selected unit in June 2020

- collected the daily fall data

- $\quad$ prepared to collect the daily number of fall risk assessments completed - no falls observed during the evaluation period

- collected the daily NHPPD data

- collected the daily census data

- collected the daily number of sitters

- evaluated the project progress/status daily

- $\quad$ reported the collected data at the weekly meetings

- facilitated weekly meetings with stakeholders

- $\quad$ aggregated data (weekly)

- obtained monthly fall rate data

These steps were coordinated with the appropriate champion(s) as identified in the timeline (see Appendix C).

The project data were disseminated to key stakeholders sharing key findings that encouraged buy-in and participation. The EBP process change updates were intended to be displayed on the unit's huddle board for increased awareness but omitted at the acute care 
nursing leadership request. Nonetheless, the information was shared with members of the clinical leadership team to ensure continuous support. The communication plan was established using various sources, including virtual meetings with video and telephone access, email, and a dedicated electronic folder in a shared drive. The electronic folder was used to file the project data, ongoing analysis, meeting minutes, progress reports, and a schedule of future events related to the project for reference.

\section{Evaluation}

This project's final stage was the evaluation phase, which Lippitt's theory refers to as the termination phase (Mitchell, 2013). This phase took place during Practicum III from 9/7/2020 through 10/22/2020. The events during this period included (see Appendix C):

- analyzed the project data using Excel Data Analysis

- reported findings to the unit leadership

- reported findings to the Patient Care Executive Board (PCEB)

- celebrated success

- reported findings to the Falls Prevention Committee

- discussed organization-wide dissemination

The evaluation phase timeline was adjusted to consider the Patient Care Executive Board (PCEB) quarterly meeting scheduled to take place on 9/24/2020. However, the meeting was canceled due to internal operational conflicts and postponed until the following quarter. The evaluation phase steps were coordinated with the appropriate champion(s) as identified in the timeline (see Appendix C).

Project management requires clear communication, planning, delegation, and time management skills (Kogon et al., 2015). Additionally, the project manager must possess 
expertise related to the interventions associated with addressing the PICOT question. Other qualities necessary include:

- flexibility to accommodate changes to support operational needs

- interprofessional collaborative skills to obtain management and staff support and buy-in

- excellent negotiation skills to ensure the project does not get derailed at the expense of other competing priorities.

The project manager reviewed the literature, presented the project for approval, and submitted the proposal through the required academic and institutional EBP approval process. Additionally, the project manager led the project through the various phases, coordinated the team meetings to monitor progress, validated the data collected, reevaluated and made changes as indicated, and reported findings upon completing the project (Vargas, 2019).

\section{Results}

The evaluation plan was used to assess if the realignment of NHPPD decreased the falls in the selected medical-surgical unit within 60 days of implementation. The fall rate was reported by the patient safety team, where falls are identified through safety reports obtained from the electronic health record and correlated with the daily nursing supervisor reports. The fall rate reports are distributed monthly with data from the previous month and aggregated to show the year-to-date data by unit and period (Vargas, 2019). Additionally, the raw number of falls and NHPPD were obtained from the daily charge nurse and the nursing supervisor reports to compare pre- and post-intervention outcomes. 


\section{Missing Data}

The data collection process is currently an established operational practice; therefore, the risk for missing data was minimal. Nonetheless, the reports were collected daily to identify gaps, validate data, and prevent missing information (Vargas, 2019).

\section{Participants}

All the patients in the evaluated unit were included and used in the established organizational fall rate reports. Therefore, the entire patient population was already a factor in this project. The staff participant selection included all the nursing supervisors in the flow center and the charge nurses. Both teams were briefed to introduce and review the project goals, intervention, expectations, roles, and timeline.

\section{Data Collection}

The project team included a project manager, nurse manager, charge nurses, nursing supervisors, and the Falls Prevention Committee chairperson. The project manager reviewed the literature, presented the project for approval, and submitted the EBP practice change project proposal to the institutional and academic review boards. Additionally, the project manager led the project through the various phases, coordinated the team meetings to monitor progress, validated the data collected, reevaluated and made changes as indicated, and reported findings once the project was completed (Vargas, 2019).

The nurse manager and the project manager coordinated the nursing supervisors' inservices, established the reporting process, and monitored compliance with the project execution as planned. Charge nurses were responsible for reporting the census and staffing as established by organizational policies. The nursing supervisors continued the existing operational process, ensuring that staffing levels were appropriate at each four-hour interval. This process considered 
the census, anticipated admissions and discharges, available resources, and NHPPD requirements, including the proposed realigned benchmark. While established institutional operational processes support the data collection responsibilities associated with this project, the project manager ensured fidelity by collecting and validating the daily reports to confirm accuracy (see Appendix F).

\section{Evaluation of Data}

Pre-intervention data were collected to establish the period with the highest number of falls in the unit evaluated. The data included all the falls reported in this unit from October 1, 2019, through May 31, 2020. During this pre-intervention period, there were 10 falls reported, five of them between the hours of 1600-2000. Therefore, this period was selected as the interval where the NHPPD would be adjusted to protect the direct nursing care hours, which was the intervention evaluated in this evidence-based practice change project.

The data to evaluate the intervention were collected over eight weeks from June 8 through August 2, 2020. There were five patient falls reported during the eight weeks, none of them during the 1600-2000 period evaluated (see Appendix I). However, the overall calculated fall rate, including the total falls outside of the time period evaluated, was 4.48/1000 bed days. This rate was consistent with the $4.76 / 1000$ bed days rate calculated on this unit in the previous fiscal year by the organization's Data Acquisition and Analytics Service (DAAS). Three of the five falls reported were assisted falls, where staff assisted the patient to the floor to avoid injury. The assisted falls are included in the organization's fall rate.

Of noteworthy consideration is that three falls occurred when the NHPPD was acceptable, while two of the five falls occurred when the NHPPD fell below the targeted benchmark. The number of falls provided data to consider the clinical significance since the 
statistical significance, although calculated at $p<0.05$, was deemed not significant once a correlation coefficient calculation demonstrated a weak relationship between NHPPD and falls (G. Gill, personal communication, September 29, 2020). These results are possibly due to the limited project timeline.

The original plan included evaluating the falls data from this unit, comparing it to a similar medical/surgical acute care unit in the organization. However, the proposal approved by the organization was limited to the unit evaluated. Therefore, the data were compared against falls data in the same unit from the same period in the previous year. This comparison was evaluated using a $t$-test: two-sample assuming unequal variances, discussed in this paper's statistical analysis section.

\section{Efforts to Minimize and Adjust for Limitations}

This project's limitations included confounding factors like staff experience and education, patient-specific co-morbidities, and realignment variances among nursing supervisors and managers (Vargas, 2019). While staff and patient-specific characteristics could not be adjusted, adherence to the recommended staffing models was managed by reinforcing the project's aim with executive leadership support (Vargas, 2019).

Furthermore, additional factors were imposed by the organization's leadership team to adhere to conditions in response to the ongoing COVID-19 pandemic. These factors included:

- discontinuation of hourly rounding

- limiting the number of units involved in each project

- reducing contact with staff 
- not disclosing information about NHPPD realignments to the nursing staff since individual NHPPD realignments were already being considered to support the creation of additional units dedicated to COVID-19 patients

\section{Formative and Summative Evaluation}

The data were aggregated and reported during the weekly project team meetings to identify gaps, develop contingencies with input from stakeholders, and to determine if modifications to the project plan were necessary to promote success. Upon completing this EBP practice change project, the project manager identified practice recommendations comparing the project's data against the standing benchmarks and suggested opportunities for policy change considerations (see Table 1).

\section{Table 1}

Summative Data

\begin{tabular}{lccl}
\hline Number of Falls & Period & Fall Rate & \multicolumn{1}{c}{ Recommendations } \\
\hline 0 & $1600-2000$ & 0 & $\begin{array}{l}\text { Comparing data against similar } \\
\text { medical/surgical acute care units }\end{array}$ \\
& $\begin{array}{l}\text { All other } \\
\text { shifts not } \\
\text { evaluated }\end{array}$ & $\begin{array}{l}4.48 / 1000 \\
\text { bed days }\end{array}$ & $\begin{array}{l}\text { Ongoing evaluation of NHPPD } \\
\text { requirements to adjust benchmarks to } \\
\text { increase direct hours during the periods of } \\
\text { highest turbulence rather than an equitable } \\
\text { distribution of resources across the } 24 \\
\text { hours }\end{array}$ \\
& & $\begin{array}{l}\text { Extending the evaluation to gather } \\
\text { additional information to determine the } \\
\text { needs at each 4-hour interval independently }\end{array}$ \\
& &
\end{tabular}

\section{Measures and Outcomes}

Three types of measures, outcome, process, and balancing were evaluated in this project. Outcome measures identify what is being assessed to promote improvement (Institute for 
Healthcare Improvement [IHI], n.d.b). The outcome measure evaluated in this project was the NHPPD realignment effect on the unit's fall rate. This measure's expected outcome was a decrease from the current rate of $3.76 / 1000$ bed days to $\leq 3.40 / 1000$ bed days, which was the average rate in the inpatient acute care setting at this institution (see Appendix G).

Process measures evaluate the steps necessary to achieve the desired outcome (IHI, n.d.b). This project's process measures included hourly rounds, percentage of post-fall huddles, percentage of fall-risk reassessments, and percentage of completed fall-prevention plans on patients identified as being at high risk for falls. The goals for these measures were anticipated as follows:

- hourly rounds - increase from $70 \%$ to $\geq 90 \%$

- $\quad$ post-fall huddles - increase from $75 \%$ to $\geq 90 \%$

- fall-risk reassessments - increase from $75 \%$ to $\geq 90 \%$

- falls prevention plan for high-fall risk patients - increase from $80 \%$ to $\geq 90 \%$ (see Appendix G)

Balancing measures are metrics that should be tracked to account for the impact on other areas (IHI, n.d.b). The balancing measures in this project were NHPPD and patient satisfaction. The expected outcome for NHPPD was to maintain the metric within $\pm 10 \%$ of the benchmark; the goal for patient satisfaction was to increase the score from 8.1 to greater than or equal to 9.0 using the current 10-point scale (see Appendix G). The patient satisfaction metric was adjusted to reflect the percentage of patients that reported a score of 9.0 or greater since this was the existing reporting method used at this organization. 
Table 2 reviews each measure identified on this project, including information about the expected outcome and the observed results with comments identifying limiting conditions that prohibited the collection of data for that measure if indicated.

Table 2

Measures

\begin{tabular}{|c|c|c|c|}
\hline Measure & Type & Goal & Results/Comment \\
\hline $\begin{array}{l}\text { Decrease Fall } \\
\text { Rate }\end{array}$ & Outcome & $\begin{array}{c}\text { Decrease from } \\
3.76 / 1000 \text { bed days to } \\
\leq 3.40 / 1000 \text { bed days }\end{array}$ & $\begin{array}{l}\text { The rate of falls observed between } \\
1600-2000 \text {, the period evaluated, } \\
\text { was } 0 \text { since no falls were reported. } \\
\text { Nonetheless, the overall fall rate, } \\
\text { including the falls that occurred } \\
\text { outside of } 1600-2000 \text {, returned a } \\
\text { calculated rate of } 4.48 / 1000 \text { bed } \\
\text { days - higher than the annual } \\
\text { reported rate from the previous } \\
\text { year but consistent with the rate } \\
\text { reported by DAAS for the same } \\
\text { months on the previous year }\end{array}$ \\
\hline $\begin{array}{l}\text { Increase Hourly } \\
\text { Rounds }\end{array}$ & Process & $\begin{array}{c}\text { Increase from } 70 \% \text { to } \geq \\
90 \%\end{array}$ & $\begin{array}{l}\text { This measure was not collected } \\
\text { since the unit stopped hourly } \\
\text { rounding during the project period }\end{array}$ \\
\hline $\begin{array}{l}\text { Increase } \\
\text { Percentage of } \\
\text { Post-Fall Huddles }\end{array}$ & Process & $\begin{array}{c}\text { Increase from } 75 \% \text { to } \geq \\
90 \%\end{array}$ & $\begin{array}{l}\text { There were no falls during the } \\
1600-2000 \text { evaluation period. The } \\
\text { percentage of completed huddles } \\
\text { for all other falls reported outside } \\
\text { of the evaluation period was } 5 / 5 \\
\text { (100\% compliance) }\end{array}$ \\
\hline $\begin{array}{l}\text { Increase } \\
\text { Percentage of } \\
\text { Fall-Risk } \\
\text { Reassessments }\end{array}$ & Process & $\begin{array}{c}\text { Increase from } 75 \% \text { to } \geq \\
90 \%\end{array}$ & $\begin{array}{l}\text { There were no falls during the } \\
1600-2000 \text { evaluation period. The } \\
\text { percentage of completed fall-risk } \\
\text { reassessment for all other falls } \\
\text { reported outside of the evaluation } \\
\text { period was } 4 / 5 \text { ( } 80 \% \text { compliance) }\end{array}$ \\
\hline $\begin{array}{l}\text { Increase } \\
\text { Percentage of } \\
\text { High Fall Risk } \\
\text { Patients with }\end{array}$ & Process & $\begin{array}{c}\text { Increase from } 80 \% \text { to } \geq \\
90 \%\end{array}$ & $\begin{array}{l}\text { There were no falls during the } \\
1600-2000 \text { evaluation period. The } \\
\text { percentage of high fall risk patients } \\
\text { with a documented fall prevention }\end{array}$ \\
\hline
\end{tabular}




\begin{tabular}{|c|c|c|c|}
\hline $\begin{array}{l}\text { Documented Falls } \\
\text { Prevention Plan }\end{array}$ & & & $\begin{array}{l}\text { plan for all other falls reported } \\
\text { outside of the evaluation period } \\
\text { was } 5 / 5 \text { ( } 100 \% \text { compliance })\end{array}$ \\
\hline NHPPD & Balancing & $\begin{array}{c}\text { Maintain within } \pm 10 \% \\
\text { of the benchmark }\end{array}$ & $\begin{array}{l}\text { The NHPPD analysis showed that } \\
7 / 56(13 \%) \text { were below the } \\
\text { recommended benchmark; } 19 / 56 \\
(34 \%) \text { within the } \pm 10 \% \text {; and } 30 / 56 \\
(54 \%) \text { periods were above the } \\
\text { benchmark - a total of } 88 \% \\
\text { meeting or exceeding the NHPPD } \\
\text { benchmark }\end{array}$ \\
\hline $\begin{array}{l}\text { Patient } \\
\text { Satisfaction }\end{array}$ & Balancing & $\begin{array}{c}* \text { Increase score from } \\
8.1 \text { to } \geq 9.0\end{array}$ & $\begin{array}{l}\text { Increase from } 63.7 \% \text { to } 69 \%- \\
* \text { Note: This measure was changed } \\
\text { to report a percentage of the } \\
\text { returned responses greater than } 9.0 \\
\text { on a scale of } 1-10 \text {. Therefore, we } \\
\text { were unable to determine the } \\
\text { number of scores that increased } \\
\text { above } 8.1\end{array}$ \\
\hline
\end{tabular}

\section{Discussion: Establishing Relationship Between Outcomes and Intervention}

The established organizational reports were used to compare fall rates between pre- and post-intervention using the nursing operations NHPPD data to evaluate for changes (Vargas, 2019). The fall rate was calculated as the number of falls divided by the number of occupied bed days for the month multiplied by 1000 . This calculation returned the rate of falls per 1,000 occupied bed days. This calculation is a validated formula established by the National Database of Nursing Quality Indicators (NDNQI), as presented by AHRQ (AHRQ, 2013).

The data collection tool used was the one developed and used by the organization's nursing operation service. This tool captured the daily census, the number of staff assigned, the number of patients on special observation protocols, and NHPPD at every four-hour tour interval. This tool's information allowed detecting the pre- and post-intervention data to use for comparison and statistical analysis testing (see Appendix E). Additional data, including patient 
age, gender, Morse fall risk level, and fall rates, were collected for potential analysis. This information was obtained from the electronic health records, financial and staffing reports, and other established organizational safety reports for further analysis (see Appendix H).

Quantitative methods were used to draw inferences from the data. Even though the $t$-test calculation returned a $p$-value $\leq 0.05$, the statistical significance was rejected since the correlation coefficient calculation between NHPPD and falls showed a weak relationship. The analysis showed that falls occurred when the NHPPD was at an acceptable benchmark level (G. Gill, personal communication, September 29, 2020). The data were analyzed using the Excel statistical package to test the difference between the means (G. Gill, personal communication, September 29, 2020). Nonetheless, since there were no falls reported during the 1600-2000 evaluation period compared to the number of falls analyzed in the pre-intervention phase that identified that $50 \%$ of the falls occurred during the same time period, we can establish that there was clinical significance.

\section{Statistical Analysis}

A two-sample assuming unequal variance $t$-test was used to calculate the differences between the fall rates from the project evaluation in 2020 and the same period in 2019. Even though the calculated results returned a $p$-value $<0.05$ (see Table 3), the statistical significance was not established since a correlation coefficient analysis returned a value of -0.219989434 , thereby indicating a weak relationship between NHPPD and falls (see Table 4). The NHPPD levels were evaluated based on the organization's definition of low, acceptable, and high. The acceptable range was $\pm 10 \%$ of the benchmark, low was below the acceptable range, and high was above the acceptable range. Although the original plan was to use Chi-square $\left(x^{2}\right)$ to test the difference between the expected frequencies and the observed frequencies of hourly rounding 
events to account for variability using SPSS, it was not completed since the hourly rounding intervention was discontinued in that unit. After consultation with a statistician, it was recommended to run a correlation coefficient using the Excel statistical package to compare the falls against the NHPPD levels when the falls occurred (G. Gill, personal communication, September 29, 2020).

\section{Table 3}

t-Test: Two-Sample Assuming Unequal Variances

\begin{tabular}{lcc}
\hline Test & (2019) $1600-2000$ Fall Rate & (2020) 1600-2000 Fall Rate \\
\hline Mean & 0.161929392 & 0 \\
Variance & 0.747224764 & 0 \\
Observations & 58 & 58 \\
Hypothesized Mean Difference & 0.5 & \\
df & 57 & \\
t Stat & -2.978487506 & \\
P $(T<=t)$ one-tail & 0.00212466 & \\
$t$ Critical one-tail & 1.672028888 & \\
$\mathrm{P}(\mathrm{T}<=\mathrm{t})$ two-tail & 0.00424932 & \\
$\mathrm{t}$ Critical two-tail & 2.002465459 & \\
\hline
\end{tabular}

\section{Table 4}

NHPPD vs. Falls Correlation Coefficient

\begin{tabular}{lcc}
\hline 2020 HPPD Scale & Frequency of Falls & Percentage of Falls \\
\hline High & 0 & $0 \%$ \\
Accept & 3 & $15 \%$ \\
Low & 2 & $29 \%$ \\
& & \\
Actual HPPD & Actual HPPD & Falls \\
Falls & 1 & \\
\hline
\end{tabular}

\section{Privacy Protection}

There are no implications affecting patient privacy since the falls data collected were already de-identified by the organization's Falls Prevention Committee. Nonetheless, the 
information was maintained in encrypted files in secured folders that were password-protected to restrict access. Furthermore, since this was an evidence-based practice change project, it was classified as exempt by the organization (J. Massengale, personal communication, October 16, 2019). While this project had a minimal risk of affecting privacy, it was presented to the organization's Ethics Committee and EBP Committee and submitted through the academic EBP process for review and approval.

\section{Impact}

The data obtained during this EBP practice change project supported the expected outcome to decrease the fall rate from $3.76 / 1000$ bed days to $\leq 3.40 / 1000$ bed days. The practice was altered by recognizing that realigning the NHPPD throughout the day was necessary to adjust direct care nursing hours according to the unit's turbulence. This NHPPD distribution was a change from their current practice, where the unit's budgeted NHPPD was allocated equitably across the 24 hours (Taylor et al., 2015).

To maximize the project's evaluation, Nurse Managers must analyze census activity and turbulence adjusting NHPPD to maximize resources. Adopting a modified NHPPD data collection tool with the fall information presented against the NHPPD at the time of the fall will promote sustainability (see Appendix E). Furthermore, a fall rate calculation worksheet similar to the one used in this EBP practice change project will also benefit the Nurse Manager's ability to analyze data to make necessary adjustments by providing ongoing evaluation (see Appendix I).

Since the operational conditions imposed during the COVID-19 pandemic limited the full implementation of this project as planned, it was recommended that the project be reproduced after the limitations are lifted. The project's limitations included reduced census during the initial phases of the pandemic, lack of staff participation, and hourly rounding discontinuation. 
Additionally, to assess the overall fall rate's effect, the project must be extended to evaluate the entire 24 hours and use other medical/surgical units in the organization for comparison. Once reevaluated, this change in practice can be extended to other medical/surgical inpatient acute care units.

\section{Plans for Dissemination}

The results were reported to the Acute Care Nursing leadership team, the unit's leadership team, and the Falls Prevention Committee Chairperson. The project presentation to the Patient Care Executive Board (PCEB) was postponed since the meeting was canceled until the following quarter due to conflicts with the ongoing pandemic-related operational priorities (see Appendix C). Therefore, the project's findings will be reported when PCEB reconvenes the third week of December. The plan is to discuss potential long-term adoption of the recommendations, dissemination throughout the agency, and review policy and procedures needed to support organizational roll-out and sustainment. The report will be made using Microsoft PowerPoint to present the project's purpose and findings, highlighting practice change recommendations and future steps.

The findings will also be shared throughout the Veterans Integrated Service Network (VISN) using the established quarterly Veterans Health Administration (VHA) regional and national process improvement forums (see Appendix C). These forums include national venues where $e$-posters are presented quarterly to share best practices. Although there is no actual cost to prepare and submit the e-poster, it is expected that the time associated with developing the poster will take approximately 5 to 6 hours, thereby having an associated cost of $\$ 300-\$ 480$ (see Appendix D). 
The final manuscript will be submitted in November for publication and archival in SOAR@USA (see Appendix C). The results will also be submitted for peer review to Doctor of Nursing Practice (DNP) staff in the organization in collaboration with the project sponsor, mentor, and the nursing education service Chief Nurse. Once reviewed by the internal staff, the manuscript will be submitted for publication consideration in the American Journal of Nursing and the MedSurg Nursing Journal. These two journals were selected because they are the ones that were identified by the organization's nursing education service as the most relevant sources to publish inpatient acute care patient falls EBP articles. Additionally, the manuscript will be submitted for consideration to Hospital Topics since this journal emphasizes topics relating to hospital administration and management. Once interest is confirmed from the publishers selected, the manuscript will be submitted to the most appropriate journal.

All three journals use a peer-review process and have specific guidelines to submit EBP manuscripts for consideration. Based on each journal's guide for authors, the anticipated timeline for publication consideration from each publisher is between 8-16 weeks (American Journal of Nursing, 2020; MedSurg Nursing, 2018; Taylor \& Francis Group, 2020). The overall process for the final publication is estimated to be between 180 and 365 days, depending on the peer review, editing, and final submission process specified by each journal. (Kathy Farrell, personal communication, March 31, 2020) (see Appendix C).

\section{Conclusion}

This project addressed a PICOT question aiming to review the effect of realigning Nursing Hours per Patient Days (NHPPD) using approved benchmarks to reduce the patient fall rate in an Acute Care Medical/Surgical inpatient unit. The NHPPD realignment occurred during the 1600-2000 four-hour interval to increase direct care nursing hours during the period 
identified as having a larger number of falls. This change was established with input from the unit Nurse Manager considering other initiatives and directives, limitations identified during the COVID-19 pandemic to ensure that the staff budget remained neutral, and to maximize staff support during the project (Vargas, 2019). The rate of falls observed between 1600-2000, the period evaluated, was 0 since no falls were reported. Nonetheless, the overall fall rate, including the falls that occurred outside of 1600-2000, returned a calculated rate of 4.48/1000 bed days higher than the annual reported rate from the previous year but consistent with the rate reported by DAAS for the same months on the previous year.

The proposal reviewed the significance of the practice problem, the framework used to support the practice change, and the literature search completed with the range of the hierarchy of the evidence. Additionally, the proposal evaluated the themes identified in the literature search, provided a description of the patient population and organizational setting, and established the congruence between the project's vision, mission, and values with those of the organization. Finally, the proposal outlined a plan with the timeline and associated costs of the EBP practice change. All these factors were used to successfully implement the practice change, evaluate the findings, and complete the dissemination plan to share best practices to impact patient outcomes positively. The findings correlated with the evidence presented in the literature review (see Appendix A). 


\section{References}

Agency for Healthcare Research and Quality. (2013). How do you measure fall rates and fall prevention practices?

https://www.ahrq.gov/professionals/systems/hospital/fallpxtoolkit/fallpxtk5.html

Agency for Healthcare Research and Quality. (2017a). Core CUSP toolkit.

https://www.ahrq.gov/professionals/education/curriculum-

tools/cusptoolkit/modules/index.html

Agency for Healthcare Research and Quality. (2017b). The CAHPS ambulatory care

improvement guide: Practical strategies for improving patient experience.

https://www.ahrq.gov/cahps/quality-improvement/improvement-guide/improvementguide.html

Alligood, M. R. (2014). Nursing Theory Utilization and Application (5th ed.). Elsevier Mosby. American Journal of Nursing. (2020). Information for authors.

http://www.medsurgnursing.net/cgi-

bin/WebObjects/MSNJournal.woa/wa/viewSection?s_id=1073744511

American Nurses Association. (n.d.). The nursing process.

https://www.nursingworld.org/practice-policy/workforce/what-is-nursing/the-nursingprocess/

Amin, A., \& Scott, L. D. (2016). Evaluating nursing hours per patient day as a nurse staffing measure. Journal of Nursing Management, 24(4), 439-448. https://doi.org/10.1111/jonm. 12347 
Baernholdt, M., Hinton, I. D., Yan, G., Xin, W., Cramer, E., \& Dunton, N. (2018). Fall rates in urban and rural nursing units does location matter? Journal of Nursing Care Quality, 33(4), 326-333. https://doi.org/10.10 97/NCQ.00000000000 00319

Bittner, C. A. (2018). The importance of role clarity for development of interprofessional teams. The Journal of Continuing Education in Nursing, 49(8), 345-347. https://doi.org/10.3928/00220124-20180718-04

Bosch, B., \& Mansell, H. (2015). Interprofessional collaboration in health care. Canadian Pharmacists Journal, 184(4), 176-179. https://doi.org/10.1177/1715163515588106

Boysen, II, P. G. (2013). Just culture: A foundation for balanced accountability and patient safety. The Ochsner Journal, 13(3), 400-406. https://www.ncbi.nlm.nih.gov/pmc/articles/PMC3776518/

Centers for Disease Control and Prevention. (2017). Important facts about falls. https://www.cdc.gov/homeandrecreationalsafety/falls/adultfalls.html

Cho, E., Chin, D. L., Kim, S., \& Hong, O. (2016). The relationships of nurse staffing level and work environment with patient adverse events. Journal of Nursing Scholarship, 48(1), 74-82. https://doi.org/10.11 11/jnu.12183

Cox, J., Thomas-Hawkins, C., Pajarillo, E., DeGennaro, S., Cadmus, E., \& Martinez, M. (2015). Factors associated with falls in hospitalized adult patients. Applied Nursing Research, 28, 78-82.

D'Andreamatteo, A., Ianni, L., Lega, F., \& Sargiacomo, M. (2015). Lean in healthcare: A comprehensive review. Health Policy, 119(9), 1197-1209. https://dx.doi.org/10.1016/j.healthpol.2015.02.002 
Dang, D., \& Dearholt, S. (2017). Johns Hopkins nursing evidence-based practice: model and guidelines (3rd ed.). Sigma Theta Tau International.

Everhart, D., Schumacher, J. R., Duncan, R., Hall, A. G., Neff, D. F., \& Shorr, R. I. (2014). Determinants of hospital fall rate trajectory groups: A longitudinal assessment of nurse staffing and organizational characteristics. Healthcare Management Review, 39(4), 352360. https://doi.org/10.1097/HMR.0000000000000013

Ganz, D. A., Huang, C., Saliba, D., Shier, V., Berlowitz, D., Lukas, C. V., \& Neumann, P. (2013). Preventing falls in hospitals: A toolkit for improving quality of care. https://www.ahrq.gov/professionals/systems/hospital/fallpxtoolkit/index.html

Golics, C. J., Azam Basra, M. K., Finlay, A. Y., \& Salek, S. (2013). The impact of disease on family members: A critical aspect of medical care. Journal of the Royal Society of Medicine, 106(10), 399-407. https://doi.org/10.1177/0141076812472616

Green, B. N., \& Johnson, C. D. (2015). Interprofessional collaboration in research, education, and clinical practice: Working together for a better future. The Journal of Chiropractic Education, 29(1), 1-10. https://doi.org/10.7899/JCE-14-36

Groysberg, B., Lee, J., \& Cheng, J. Y. (2018). What's your organization's cultural profile? Harvard Business Review. https://hbr.org/2018/01/the-culture-factor\#whats-yourorganizations-cultural-profile

He, J., Staggs, V. S., Bergquist-Beringer, S., \& Dutton, N. (2016). Nurse staffing and patient outcomes: A longitudinal study on trend and seasonality. BMC Nursing, 15(60), 1-10. https://doi.org/10.1186/s12912-016-0181-3

Institute for Healthcare Improvement. (n.d.a). IHI triple aim. http://www.ihi.org/Engage/Initiatives/TripleAim/Pages/default.aspx 
Institute for Healthcare Improvement. (n.d.b). Science of improvement: Establishing measures. http://www.ihi.org/resources/Pages/HowtoImprove/ScienceofImprovementEstablishingM easures.aspx

James A. Haley Veterans Hospital. (2017). Fast facts. https://www.tampa.va.gov/careers/images/JAHVH_FactSheet_July_2018.jpg

James A. Haley Veterans Hospital. (n.d.). On-boarding process for new employee. https://www.tampa.va.gov/careers/neo.asp

Kim, J., Kim, S., Park, J., \& Lee, E. (2019). Multilevel factors influencing falls of patients in hospital: The impact of nurse staffing. Journal of Nursing Management, 27(5), 10111019. https://doi.org/10.1111/jonm.12765

Kogon, K., Blakemore, S., \& Wood, J. (2015). Project management for the unofficial project manager. Dallas, TX: BenBella Books.

Koualty, I. A., Nassar, N., Nizam, M., \& Badr, L. K. (2018). Evidence on nurse staffing ratios and patient outcomes in a low-income country: Implications for future research and practice. Worldviews on Evidence-Based Nursing, 15(5), 353-360. https://doi.org/10.1111/wvn.12316

MedSurg Nursing. (2018). Author guidelines. http://www.medsurgnursing.net/cgibin/WebObjects/MSNJournal.woa/wa/viewSection?s_id=1073744511

Mitchell, G. (2013). Selecting the best theory to implement planned change. Nursing Management, 20(1), 32-37. https://doi.org/10.7748/nm2013.04.20.1.32.e1013

National Council on Aging. (n.d.). Falls prevention facts. https://www.ncoa.org/news/resourcesfor-reporters/get-the-facts/falls-prevention-facts/ 
Spear, M. (2016). How to facilitate change. American Society of Plastic Surgical Nurses, 36(2), 58-61. https://doi.org/10.1097/PSN.0000000000000139

Staggs, V. S., Mion, L. C., \& Shorr, R. I. (2015). Consistent differences in medical unit fall rates: Implications for research and practice. Journal of the American Geriatrics Society, 63(5), 983-987. https://doi.org/10.11 11/jgs.13387

Stalpers, D., de Brouwer, B. J., \& Kaljouw, M. J. (2015). Associations between characteristics of the nurse work environment and five nurse-sensitive patient outcomes in hospitals: A systematic review of literature. International Journal of Nursing Studies, 52, 817-835.

Stoeckle, A., Iseler, J. I., Havey, R., \& Aebersold, C. (2018). Catching quality before it falls: Preventing falls and injuries in the adult emergency department. Journal of Emergency Nursing, 45(3), 1-8. https://doi.org/10.1016/j.jen.2018.08.001

Taylor \& Francis Group. (2020). Author services. https://authorservices.taylorandfrancis.com/ Taylor, B., Yankey, N., Robinson, C., Annis, A., Haddock, K. S., Alt-White, A., ... Sales, A. (2015). Evaluating the Veterans Health Administration's staffing methodology model: A reliable approach. Nursing Economic\$, 33(1), 36-40, 66.

U.S. Department of Veterans Affairs. (n.d.a). About VHA. https://www.va.gov/health/aboutvha.asp

U.S. Department of Veterans Affairs. (n.d.b). I CARE core values. https://www.va.gov/ICARE/index.asp

U.S. Department of Veterans Affairs. (n.d.c). VA sunshine healthcare network. https://www.visn8.va.gov/VISN8/about/index.asp

Vargas, H. O. (2018). Search strategy and Prisma model. Unpublished manuscript.

Vargas, H. O. (2019). SQUIRE. Unpublished manuscript. 
Walsh, C. M., Liang, L., Grogan, T., Coles, C., McNair, N., \& Nuckols, T. K. (2018). Temporal trends in fall rates with the implementation of a multifaceted fall prevention program: Persistence pays off. The Joint Commission Journal on Quality and Patient Safety, 44(2), 75-83. https://doi.org/10.1016/j.jcjq.2017.08.009

World Health Organization. (2018). Falls. https://www.who.int/news-room/factsheets/detail/falls

Zadvinskis, I. M., Carr, J., \& Schweitzer, K. E. (2019). The impact of nursing work and engagement on patient falls. The Journal of Nursing Administration, 49(11), 531-537. https://doi.org/10.1097/NNA.0000000000000808 
Figure 1.

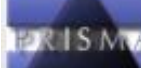

PRISMA 2009 Flow Diagram
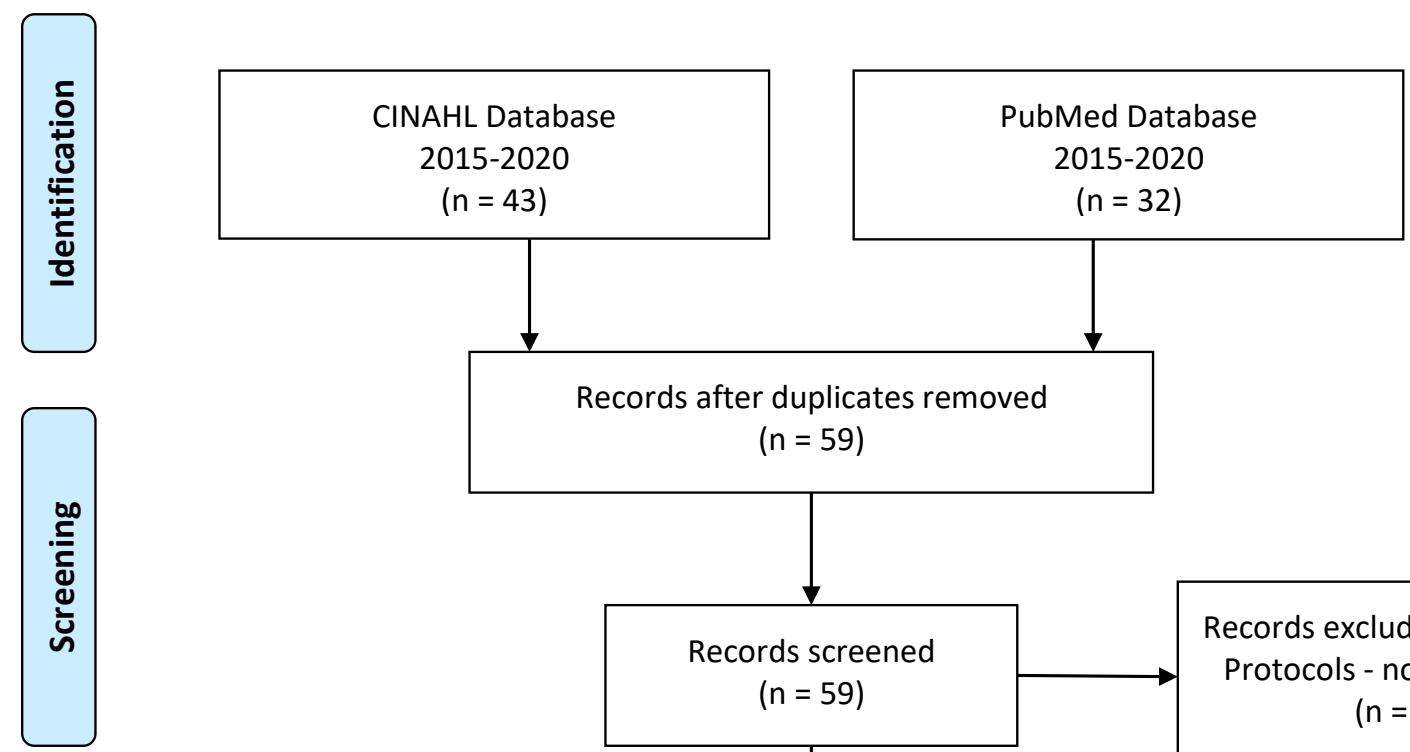

Records after duplicates removed

$(n=59)$
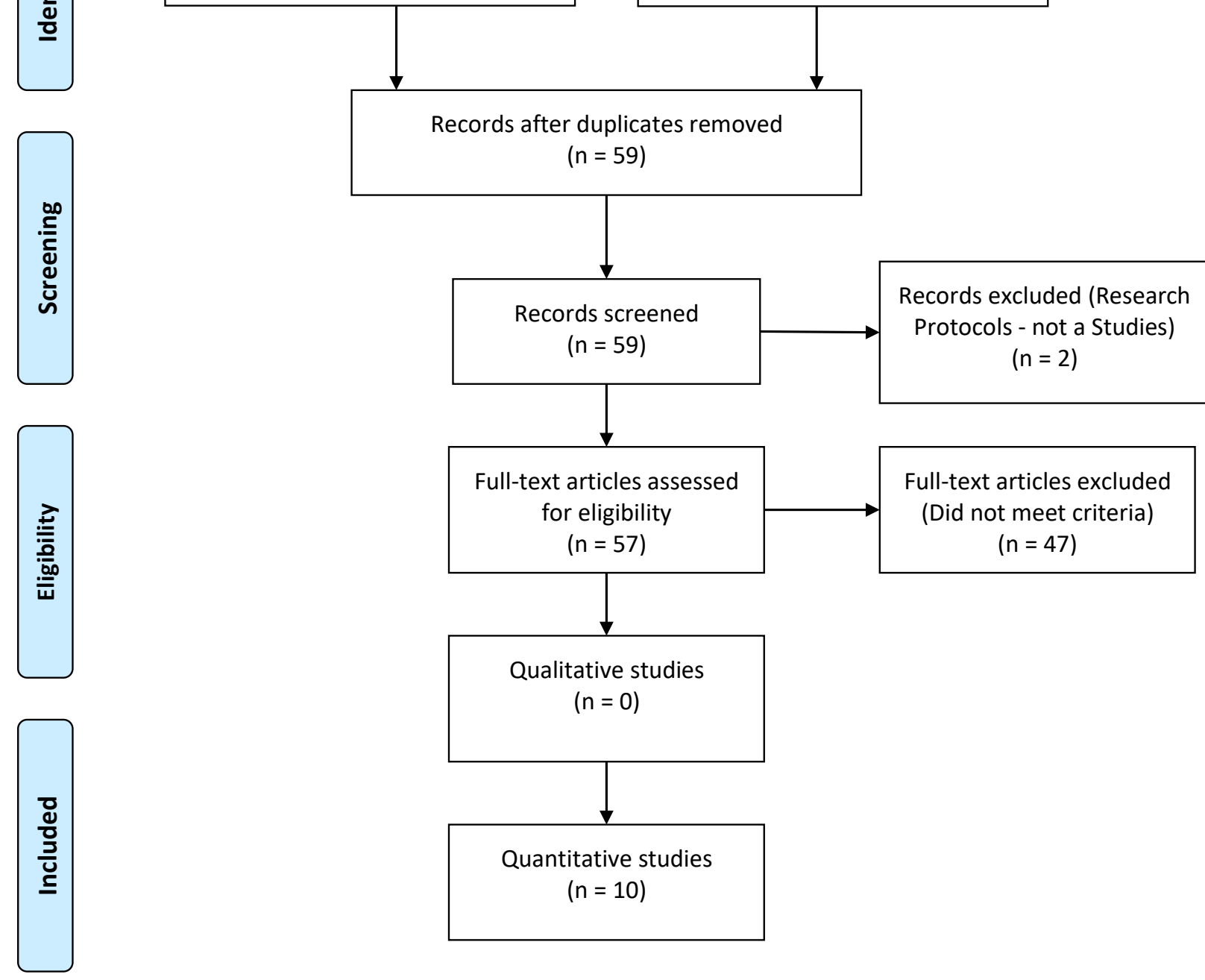

Moher, D., Liberati, A., Tetzlaff, J., \& Altman, D. G. (2009). Preferred reporting items for systematic reviews and meta-analyses: The PRISMA statement. PLoS Medicine, 6(7), 16. https://doi.org/10.1371/journal.pmed.1000097 
Figure 2.

\section{Fall Prevention Themes}

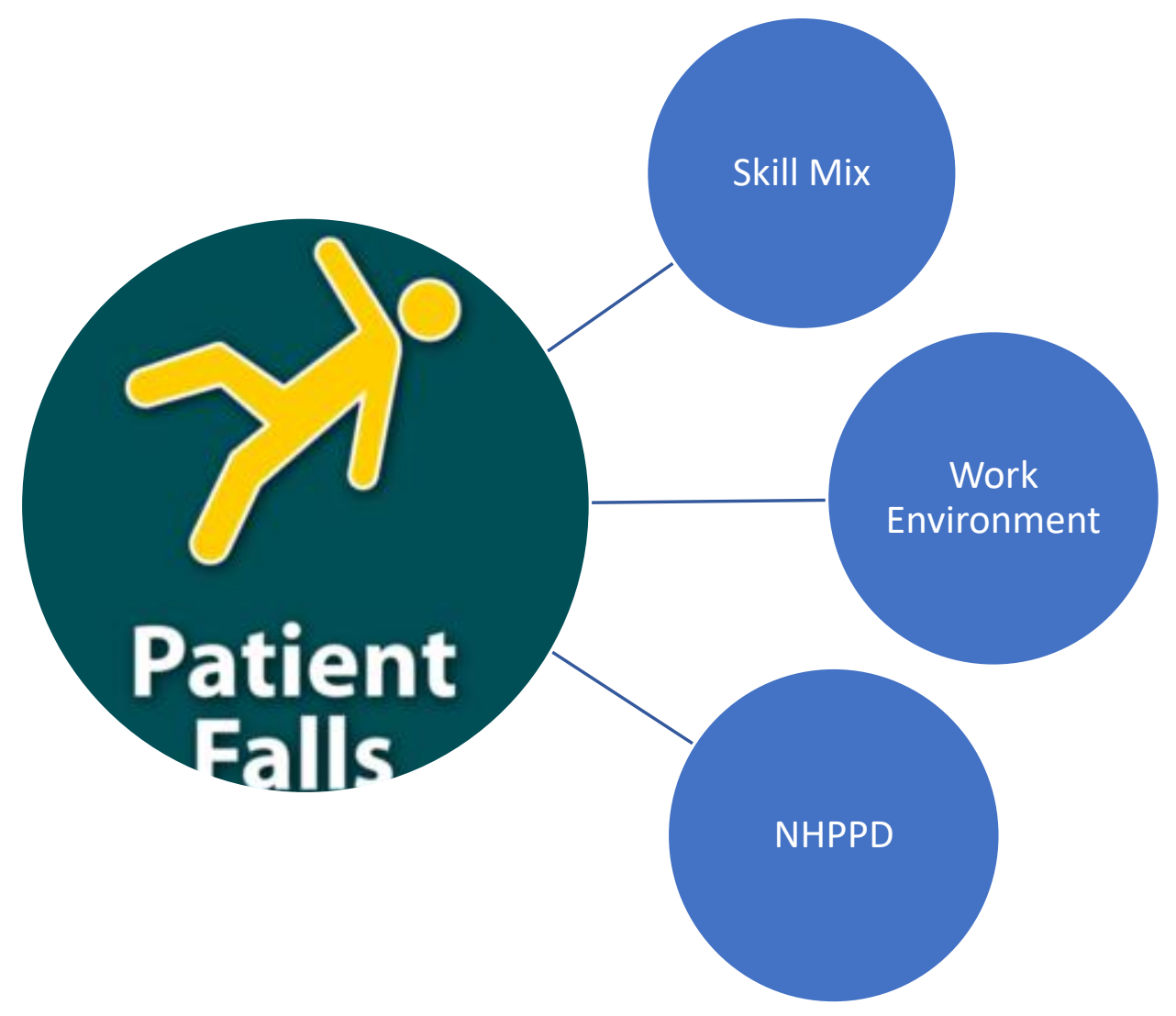


Figure 3.

\section{SWOT Analysis}

\section{Strengths}

- Teamwork

- Leadership Team's Experience

- Interdiciplinary Collaboration

- Commitment to Process Improvement \& Evidence-Based Practice

- Low Turnover Rate

\begin{tabular}{|l|}
\hline \multicolumn{1}{|c|}{ Opportunities } \\
\hline - Cerner EHR - VA/DOD \\
Interoperability \\
- Hourly Rounding \\
- Bedside Report \\
- NHPPD Optimization \& Staff \\
Education \\
- Nursing Operational Process \\
\hline
\end{tabular}

\section{Weaknesses}

- Outdated EMR

- Four-bed Rooms

- Long On-boarding HR Process

- Insufficient Number of Techs/Sitters

- Inadequate Float Pool Process

- Lack of Standardized Operational

Practices

\begin{tabular}{|l|}
\hline \multicolumn{1}{|c|}{ Threats } \\
\hline - Turbulence \\
- Staff Age \\
- Leadership Retirement \\
- Competing Priorities \\
\\
\hline
\end{tabular}


Figure 4.

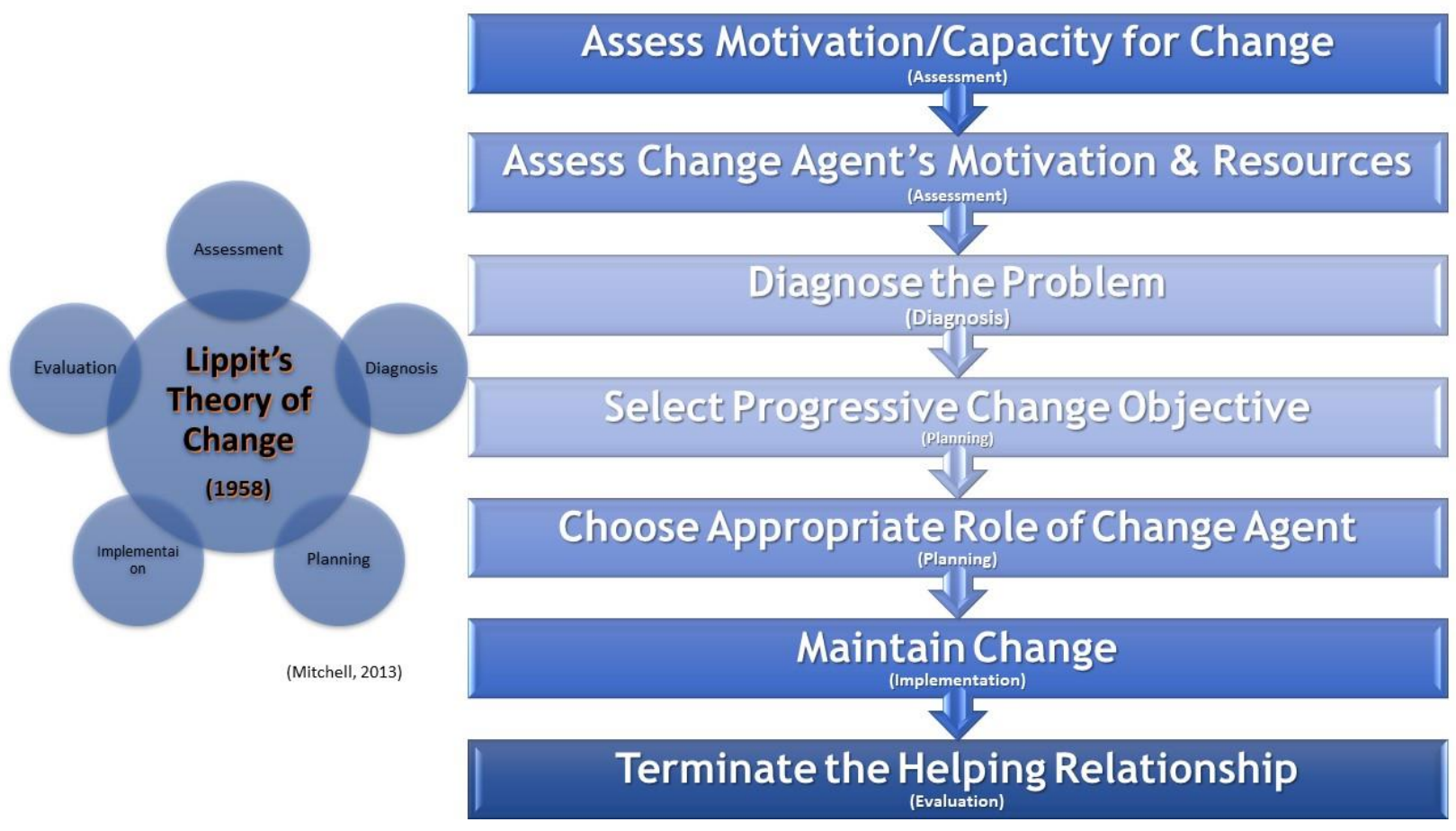


Appendix A

Summary of Primary Research Evidence

\begin{tabular}{|c|c|c|c|c|c|c|}
\hline Citation & $\begin{array}{c}\text { Design, Level of } \\
\text { Evidence/ Quality } \\
\text { Grade }\end{array}$ & $\begin{array}{l}\text { Sample } \\
\text { Size }\end{array}$ & $\begin{array}{l}\text { Intervention, } \\
\text { Comparison, } \\
\text { \& Definitions }\end{array}$ & $\begin{array}{l}\text { Theoretical } \\
\text { Foundation }\end{array}$ & Outcome Definition & Results - Key Findings \\
\hline $\begin{array}{l}\text { Baernholdt, M., Hinton, I. D., } \\
\text { Yan, G., Xin, W., } \\
\text { Cramer, E., \& Dunton, } \\
\text { N. (2018). Fall rates in } \\
\text { urban and rural } \\
\text { nursing units does } \\
\text { location matter? } \\
\text { Journal of Nursing } \\
\text { Care Quality, 33(4), } \\
\text { 326-333. } \\
\text { http://dx.doi.org/10.10 } \\
\text { 97/NCQ.00000000000 } \\
\text { 00319 }\end{array}$ & $\begin{array}{l}\text { Cross-sectional } \\
\text { study } \\
\text { Johns Hopkins } \\
\text { Nursing EBP Level } \\
\text { of Evidence/Quality } \\
\text { Grade: IIB }\end{array}$ & $\begin{array}{l}\mathrm{N}=4274 \\
\text { units in } 625 \\
\text { hospitals } \\
\text { (65 rural \& } \\
560 \text { urban) }\end{array}$ & $\begin{array}{l}\text { Analysis of } \\
\text { geographic } \\
\text { location, } \\
\text { hospital \& } \\
\text { nursing } \\
\text { characteristics } \\
\text { (including } \\
\text { nurse staff } \\
\text { hours), and } \\
\text { patient falls } \\
\text { extracted from } \\
\text { NDNQI }^{\circledR}\end{array}$ & $\begin{array}{l}\text { None } \\
\text { reported; } \\
\text { however, the } \\
\text { authors } \\
\text { mention } \\
\text { Nursing } \\
\text { Foundation } \\
\text { for Quality } \\
\text { of Care as a } \\
\text { practice } \\
\text { environment } \\
\text { measuremen } \\
\mathrm{t}\end{array}$ & $\begin{array}{l}\text { This study examined } \\
\text { associations } \\
\text { between } \\
\text { fall rates and the } \\
\text { environment } \\
\text { (geographic } \\
\text { location), } \\
\text { organization } \\
\text { (hospital } \\
\text { characteristics), } \\
\text { and microsystem } \\
\text { (nursing unit } \\
\text { characteristics). }\end{array}$ & $\begin{array}{l}\text { Fall rates are affected by } \\
\text { staffing, education, and } \\
\text { experience. An hour } \\
\text { increase in care by all } \\
\text { staff members decreased fall } \\
\text { rates by } 8 \% \text {, and } \\
\text { an hour increase in care by } \\
\text { RNs decreased fall } \\
\text { rates by } 10 \%\end{array}$ \\
\hline $\begin{array}{c}\text { Cho, E., Chin, D. L., Kim, S., } \\
\text { \& Hong, O. (2016). } \\
\text { The relationships of } \\
\text { nurse staffing level } \\
\text { and work environment } \\
\text { with patient adverse } \\
\text { events. Journal of } \\
\text { Nursing Scholarship, } \\
\text { 48(1), 74-82. } \\
\text { http://dx.doi.org/10.11 } \\
\text { 11/jnu.12183 }\end{array}$ & $\begin{array}{l}\text { Cross-sectional } \\
\text { study using a } \\
\text { combination of } \\
\text { nurse survey data (N } \\
=4,864 \text { nurses), } \\
\text { facility data (N = } 58 \\
\text { hospitals), and } \\
\text { patient hospital } \\
\text { discharge data (N = } \\
113,426 \text { patients) } \\
\text { Johns Hopkins } \\
\text { Nursing EBP Level } \\
\text { of Evidence/Quality } \\
\text { Grade: IIB }\end{array}$ & $\begin{array}{l}\mathrm{N}=4,864 \\
\text { Nurse } \\
\text { Safety data; } \\
\mathrm{N}=58 \\
\text { hospitals); } \\
\text { and } \mathrm{N}= \\
113,426 \\
\text { patient } \\
\text { hospital } \\
\text { discharged } \\
\text { patients }\end{array}$ & $\begin{array}{l}\text { Analysis of a } \\
\text { combination of } \\
\text { nurse survey } \\
\text { data, facility } \\
\text { data and } \\
\text { patient } \\
\text { hospital } \\
\text { discharge data }\end{array}$ & None & $\begin{array}{l}\text { Outcomes in this } \\
\text { study were defined } \\
\text { by patient adverse } \\
\text { events, including } \\
\text { injury from falling } \\
\text { after admission. }\end{array}$ & $\begin{array}{l}\text { A larger number of patients } \\
\text { per nurse was significantly } \\
\text { associated with a higher } \\
\text { incidence of patient falls } \\
\text { with injury }\end{array}$ \\
\hline $\begin{array}{l}\text { Cox, J., Thomas-Hawkins, C., } \\
\text { Pajarillo, E., } \\
\text { DeGennaro, S., } \\
\text { Cadmus, E., \& } \\
\text { Martinez, M. (2015). } \\
\text { Factors associated } \\
\text { with falls in }\end{array}$ & $\begin{array}{l}\text { Descriptive, } \\
\text { correlational, } \\
\text { retrospective study } \\
\text { Johns Hopkins } \\
\text { Nursing EBP Level }\end{array}$ & $\begin{array}{l}\mathrm{N}=160 \\
\text { patients } \\
\text { admitted to } \\
\text { a medical- } \\
\text { surgical } \\
\text { unit in a } \\
\text { 500-bed }\end{array}$ & $\begin{array}{l}\text { Analysis of } \\
\text { fall data } \\
\text { abstracted } \\
\text { from the } \\
\text { 'institution's } \\
\text { electronic } \\
\text { medical record }\end{array}$ & None & $\begin{array}{l}\text { Outcome of the } \\
\text { study was to } \\
\text { decrease or prevent } \\
\text { adverse events for } \\
\text { patients at risk for } \\
\text { falling. }\end{array}$ & $\begin{array}{l}\text { While causes of falls are } \\
\text { multifactorial and should } \\
\text { form the basis for a } \\
\text { complete fall-risk } \\
\text { assessment, the authors } \\
\text { concluded that higher }\end{array}$ \\
\hline
\end{tabular}




\begin{tabular}{|c|c|c|c|c|c|c|}
\hline $\begin{array}{l}\text { hospitalized adult } \\
\text { patients. Applied } \\
\text { Nursing Research, 28, } \\
78-82 \text {. } \\
\text { http://dx.doi.org/10.10 } \\
\text { 16/j.apnr.2014.12.003 }\end{array}$ & $\begin{array}{l}\text { of Evidence/Quality } \\
\text { Grade: IIB }\end{array}$ & $\begin{array}{l}\text { Magnet } \\
\text { teaching } \\
\text { hospital }\end{array}$ & $\begin{array}{l}\text { (EMR) from } \\
\text { all patients } \\
\text { admitted to a } \\
\text { medical/surgic } \\
\text { al unit in } 2012\end{array}$ & & & $\begin{array}{l}\text { RN/UAP ratio significantly } \\
\text { predicted a decreased } \\
\text { likelihood of falls }\end{array}$ \\
\hline $\begin{array}{l}\text { He, J., Staggs, V. S., Bergquist- } \\
\text { Beringer, S., \& } \\
\text { Dutton, N. (2016). } \\
\text { Nurse staffing and } \\
\text { patient outcomes: A } \\
\text { longitudinal study on } \\
\text { trend and seasonality. } \\
\text { BMC Nursing, 15(60), } \\
\text { 1-10. } \\
\text { http://dx.doi.org/10.11 } \\
\text { 86/s12912-016-0181-3 }\end{array}$ & $\begin{array}{l}\text { Descriptive, } \\
\text { longitudinal study } \\
\text { Johns Hopkins } \\
\text { Nursing EBP Level } \\
\text { of Evidence/Quality } \\
\text { Grade: IIB }\end{array}$ & $\begin{array}{l}\mathrm{N}=13,339 \\
\text { units with } \\
\text { at least one } \\
\text { year of data } \\
\text { with data in } \\
\text { all four } \\
\text { quarters } \\
\text { from } 1622 \\
\text { hospitals }\end{array}$ & $\begin{array}{l}\text { Analysis of } \\
\text { monthly nurse } \\
\text { staffing and } \\
\text { inpatient falls } \\
\text { data extracted } \\
\text { from NDNQI }{ }^{\circledR}\end{array}$ & None & $\begin{array}{l}\text { Patient outcomes } \\
\text { included rates of } \\
\text { inpatient falls. } \\
\text { Staffing variables } \\
\text { included total } \\
\text { nursing hours per } \\
\text { patient days } \\
\text { (NHPPD) and } \\
\text { percent of nursing } \\
\text { hours provided by } \\
\text { registered nurses } \\
\text { (RN skill-mix). }\end{array}$ & $\begin{array}{l}\text { Changes in nurse staffing } \\
\text { were inversely associated } \\
\text { with changes in the rates of } \\
\text { falls at both the time trend } \\
\text { and the seasonal levels. The } \\
\text { authors hypothesize that } \\
\text { increased staffing levels } \\
\text { contributed to reducing falls }\end{array}$ \\
\hline $\begin{array}{l}\text { Kim, J., Kim, S., Park, J., \& } \\
\text { Lee, E. (2019). } \\
\text { Multilevel factors } \\
\text { influencing falls of } \\
\text { patients in hospital: } \\
\text { The impact of nurse } \\
\text { staffing. Journal of } \\
\text { Nursing Management, } \\
\text { 27(5), 1011-1019. } \\
\text { http://dx.doi.org/10.11 } \\
\text { 11/jonm.12765 }\end{array}$ & $\begin{array}{l}\text { Descriptive, } \\
\text { correlational, } \\
\text { retrospective study } \\
\text { Johns Hopkins } \\
\text { Nursing EBP Level } \\
\text { of Evidence/Quality } \\
\text { Grade: IIB }\end{array}$ & $\begin{array}{l}\mathrm{N}=60,049 \\
\text { patients } \\
\text { from } 275 \\
\text { hospitals }\end{array}$ & $\begin{array}{l}\text { Analysis of } \\
\text { data from the } \\
\text { National } \\
\text { Health } \\
\text { Insurance } \\
\text { (NHI) } \\
\text { in Korea }\end{array}$ & None & $\begin{array}{l}\text { The outcome of the } \\
\text { study was to identify } \\
\text { individual } \\
\text { and organizational } \\
\text { factors influencing } \\
\text { patient falls. }\end{array}$ & $\begin{array}{l}\text { Age, mobility, impairment, } \\
\text { and RN nursing hours per } \\
\text { patient day are factors } \\
\text { influencing patient falls. }\end{array}$ \\
\hline $\begin{array}{l}\text { Kouatly, I. A., Nassar, N., } \\
\text { Nizam, M., \& Badr, L. } \\
\text { K. (2018). Evidence } \\
\text { on nurse staffing ratios } \\
\text { and patient outcomes } \\
\text { in a low-income } \\
\text { country: Implications } \\
\text { for future research and } \\
\text { practice. Worldviews } \\
\text { on Evidence-Based } \\
\text { Nursing, 15(5), 353- } \\
\text { 360. } \\
\text { http://dx.doi.org/10.11 } \\
\text { 11/wvn.12316 }\end{array}$ & $\begin{array}{l}\text { Prospective cross- } \\
\text { sectional study } \\
\text { Johns Hopkins } \\
\text { Nursing EBP Level } \\
\text { of Evidence/Quality } \\
\text { Grade: IIC }\end{array}$ & $\begin{array}{l}\mathrm{N}=532 \\
\text { nurses }\end{array}$ & $\begin{array}{l}48 \text {-month } \\
\text { study } \\
\text { comparing } \\
\text { nurse staffing } \\
\text { characteristics } \\
\text { against nurse- } \\
\text { sensitive } \\
\text { outcomes }\end{array}$ & None & $\begin{array}{l}\text { The outcome was to } \\
\text { determine the } \\
\text { relationship between } \\
\text { staffing and nurse- } \\
\text { sensitive outcomes } \\
\text { (NSO), including } \\
\text { falls. Nurse } \\
\text { staffing was } \\
\text { measured by nursing } \\
\text { hours per patient } \\
\text { day (NHPPD) and } \\
\text { skill mix and }\end{array}$ & $\begin{array}{l}\text { NSOs were significantly } \\
\text { related to lower NHPPD } \\
\text { rates. } \\
\text { Fall rates decrease as } \\
\text { staffing increases, and } \\
\text { higher levels of non-RN } \\
\text { staffing were associated } \\
\text { with higher fall rates. } \\
\text { Additionally, individual } \\
\text { staff characteristics, work } \\
\text { environments, and patient }\end{array}$ \\
\hline
\end{tabular}




\begin{tabular}{|c|c|c|c|c|c|c|}
\hline & & & & & $\begin{array}{l}\text { total falls were } \\
\text { reported per } 1,000 \\
\text { patient days. }\end{array}$ & $\begin{array}{l}\text { care needs must be } \\
\text { considered. }\end{array}$ \\
\hline $\begin{array}{l}\text { Staggs, V. S., Mion, L. C., \& } \\
\text { Shorr, R. I. (2015). } \\
\text { Consistent differences } \\
\text { in medical unit fall } \\
\text { rates: Implications for } \\
\text { research and practice. } \\
\text { Journal of the } \\
\text { American Geriatrics } \\
\text { Society, 63(5), 983- } \\
\text { 987. } \\
\text { http://dx.doi.org/10.11 } \\
\text { 11/jgs.13387 }\end{array}$ & $\begin{array}{l}\text { Retrospective study } \\
\text { of administrative } \\
\text { data } \\
\text { Johns Hopkins } \\
\text { Nursing EBP Level } \\
\text { of Evidence/Quality } \\
\text { Grade: IIB }\end{array}$ & $\begin{array}{l}\mathrm{N}=800 \\
\text { Non- } \\
\text { subspecialt } \\
\text { y medical } \\
\text { units from } \\
70 \\
\text { hospitals }\end{array}$ & $\begin{array}{l}\text { Analysis of } 24 \\
\text { consecutive } \\
\text { months of data } \\
\text { extracted from } \\
\text { NDNQI }^{\circledR}\end{array}$ & None & $\begin{array}{l}\text { This study was } \\
\text { designed to evaluate } \\
\text { hospital level and } \\
\text { individual unit } \\
\text { characteristics to } \\
\text { determine how they } \\
\text { affect fall rate } \\
\text { variability. }\end{array}$ & $\begin{array}{l}\text { Fall rates vary between } \\
\text { nursing units with similar } \\
\text { types of patients. The fall } \\
\text { rate variability may be } \\
\text { attributed to differences } \\
\text { between unit characteristics } \\
\text { and patient days. }\end{array}$ \\
\hline $\begin{array}{l}\text { Zadvinskis, I. M., Carr, J., } \\
\text { Schweitzer, K. E., } \\
\text { Patil, N., Clifton, W. } \\
\text { D., \& Ebert, K. E. } \\
\text { (2019). The impact of } \\
\text { nursing work and } \\
\text { engagement on patient } \\
\text { falls. The Journal of } \\
\text { Nursing } \\
\text { Administration, } \\
\text { 49(11), 531-537. } \\
\text { http://dx.doi.org/10.10 } \\
\text { 97/NNA.00000000000 } \\
\text { 00808 }\end{array}$ & $\begin{array}{l}\text { Descriptive, cross- } \\
\text { sectional, } \\
\text { survey design } \\
\text { Johns Hopkins } \\
\text { Nursing EBP Level } \\
\text { of Evidence/Quality } \\
\text { Grade: IIIC }\end{array}$ & $\begin{array}{l}\mathrm{N}=41 \\
\text { nursing } \\
\text { units from } \\
7 \\
\text { hospitals; } \\
\text { Convenien } \\
\text { ce sample } \\
\text { Only } 2 \\
\text { quarters of } \\
\text { falls data }\end{array}$ & $\begin{array}{l}\text { Analysis of } \\
\text { relationships } \\
\text { between } \\
\text { NHPPD, skill } \\
\text { mix, unit type, } \\
\text { work } \\
\text { engagement, } \\
\text { and frequency } \\
\text { of fall risk }\end{array}$ & $\begin{array}{l}\text { Donabedian } \\
\text { model } \\
\text { served as the } \\
\text { conceptual } \\
\text { framework } \\
\text { to determine } \\
\text { the effect of } \\
\text { nurse- } \\
\text { sensitive } \\
\text { structures } \\
\text { and } \\
\text { processes on } \\
\text { patient falls }\end{array}$ & $\begin{array}{l}\text { The study was } \\
\text { designed to compare } \\
\text { relationships among } \\
\text { process variables; } \\
\text { and to determine } \\
\text { if nursing processes } \\
\text { predicted frequency } \\
\text { of patient falls and } \\
\text { falls with injury }\end{array}$ & $\begin{array}{l}\text { This study did not } \\
\text { demonstrate a statistically } \\
\text { significant association } \\
\text { between NHPPD, skill mix, } \\
\text { unit type, work engagement, } \\
\text { and frequency of fall risk. } \\
\text { However, the authors } \\
\text { identified cross-sectional } \\
\text { data as limiting the ability to } \\
\text { detect cause/effect and } \\
\text { temporal trends. They also } \\
\text { mentioned that further } \\
\text { research is needed using } \\
\text { additional and alternative } \\
\text { variables to explain the } \\
\text { impact of nursing work on } \\
\text { patient outcomes. }\end{array}$ \\
\hline
\end{tabular}

Legend:

UAP - Unlicensed Assistive Personnel

NDNQI - National Database of Nursing Quality Indicators ${ }^{\circledR}$

NSO - Nurse Sensitive Outcome 
Appendix B

Summary of Systematic Reviews (SR)

\begin{tabular}{|c|c|c|c|c|c|c|}
\hline Citation & $\begin{array}{l}\text { Quality } \\
\text { Grade }\end{array}$ & Question & $\begin{array}{l}\text { Inclusion / } \\
\text { Exclusion } \\
\text { Criteria } \\
\end{array}$ & $\begin{array}{c}\text { Data Extraction and } \\
\text { Analysis }\end{array}$ & Key Findings & $\begin{array}{c}\text { Usefulness / } \\
\text { Recommendations / } \\
\text { Implications }\end{array}$ \\
\hline $\begin{array}{l}\text { Min, A., \& Scott, L. D. } \\
\text { (2016). } \\
\text { Evaluating } \\
\text { nursing hours } \\
\text { per patient day } \\
\text { as a nurse } \\
\text { staffing } \\
\text { measure. } \\
\text { Journal of } \\
\text { Nursing } \\
\text { Management, } \\
\text { 24(4), 439-448. } \\
\text { http://dx.doi.org } \\
\text { /10.1111/jonm. } \\
\text { 12347 }\end{array}$ & $\begin{array}{l}\text { Johns } \\
\text { Hopkins } \\
\text { Nursing } \\
\text { EBP } \\
\text { Level of } \\
\text { Evidence / } \\
\text { Quality } \\
\text { Grade: IIB }\end{array}$ & $\begin{array}{l}\text { Is NHPPD a } \\
\text { reliable method } \\
\text { to determine the } \\
\text { predictive } \\
\text { validity for } \\
\text { better patient } \\
\text { outcomes? }\end{array}$ & $\begin{array}{l}\text { Inclusion } \\
\text { criteria: nurse } \\
\text { staffing } \\
\text { measures, } \\
\text { published in } \\
\text { peer-reviewed } \\
\text { journals, } \\
\text { available in the } \\
\text { English } \\
\text { language. } \\
\text { The authors did } \\
\text { not report any } \\
\text { exclusion } \\
\text { 14 studies } \\
\text { included: } 6 \\
\text { cross-sectional; } 1 \\
\text { cross-sectional } \\
\text { correlational; } 4 \\
\text { correlational; } 2 \\
\text { longitudinal; } 1 \\
\text { retrospective }\end{array}$ & $\begin{array}{l}\text { Sources searched: } \\
\text { CINAHL, PubMed, and } \\
\text { Google Scholar. } \\
\text { Keywords used: nurse } \\
\text { staffing, reliability, and } \\
\text { validity. Additional } \\
\text { searches were performed } \\
\text { with terms associated } \\
\text { with nurse-to-patient } \\
\text { ratios, nurse-perceived } \\
\text { staffing adequacy, and } \\
\text { nurse-reported number of } \\
\text { assigned patients. The } \\
\text { authors selected } 17 \\
\text { articles; } 14 \text { studies used } \\
\text { nurse staffing measures, } \\
\text { and three studies tested } \\
\text { the reliability of a nurse } \\
\text { staffing measure. }\end{array}$ & $\begin{array}{l}\text { The NHPPD } \\
\text { measure } \\
\text { demonstrates } \\
\text { inter-rater } \\
\text { reliability and } \\
\text { predictive } \\
\text { validity for } \\
\text { patient fall rates. }\end{array}$ & $\begin{array}{l}\text { The authors reported that } \\
\text { while NHPPD is a reliable } \\
\text { measure with predictive } \\
\text { validity to determine } \\
\text { staffing levels to promote } \\
\text { better outcomes associated } \\
\text { with patient fall rates, } \\
\text { further reliability testing } \\
\text { with other types of units and } \\
\text { larger sample sizes are } \\
\text { required to determine the } \\
\text { predictive validity for } \\
\text { different patient outcomes. } \\
\text { They further identified that } \\
\text { adjustments in the ' } \\
\text { 'measure's application are } \\
\text { necessary to capture patient, } \\
\text { staff, and organizational } \\
\text { characteristic variations. }\end{array}$ \\
\hline $\begin{array}{l}\text { Stalpers, D., de Brouwer, } \\
\text { B. J., Kaljouw, } \\
\text { M. J., \& } \\
\text { Schuurmans, } \\
\text { M. J. (2015). } \\
\text { Associations } \\
\text { between } \\
\text { characteristics } \\
\text { of the nurse } \\
\text { work } \\
\text { environment } \\
\text { and five nurse- }\end{array}$ & $\begin{array}{l}\text { Johns } \\
\text { Hopkins } \\
\text { Nursing } \\
\text { EBP } \\
\text { Level of } \\
\text { Evidence / } \\
\text { Quality } \\
\text { Grade: IIB }\end{array}$ & $\begin{array}{l}\text { Are there } \\
\text { associations } \\
\text { between } \\
\text { characteristics } \\
\text { of the nurse } \\
\text { work } \\
\text { environment } \\
\text { (nurse staffing, } \\
\text { nurse/physician } \\
\text { collaboration) } \\
\text { and nurse- } \\
\text { sensitive patient }\end{array}$ & $\begin{array}{l}\text { The studies } \\
\text { selected } \\
\text { examined } \\
\text { associations } \\
\text { between the } \\
\text { work } \\
\text { environment and } \\
\text { nurse-sensitive } \\
\text { patient } \\
\text { outcomes in } \\
\text { hospitals, had a }\end{array}$ & $\begin{array}{l}\text { Sources searched: } \\
\text { Medline (PubMed), } \\
\text { Cochrane Library, } \\
\text { Embase, and CINAHL. } \\
\text { Search terms were } \\
\text { determined by screening } \\
\text { abstracts and reference } \\
\text { lists of reviews on the } \\
\text { nurse work environment } \\
\text { generating an extensive } \\
\text { list of terms shown in a } \\
\text { figure included in the }\end{array}$ & $\begin{array}{l}\text { Higher staffing } \\
\text { numbers are } \\
\text { associated with } \\
\text { fewer patient } \\
\text { falls. }\end{array}$ & $\begin{array}{l}\text { The authors recommend } \\
\text { randomized controlled } \\
\text { trials as the preferred } \\
\text { research design, but note } \\
\text { that it is almost impossible } \\
\text { to use these designs in the } \\
\text { present research } \\
\text { area, because it requires } \\
\text { randomization of } \\
\text { interventions } \\
\text { that cannot be controlled. }\end{array}$ \\
\hline
\end{tabular}




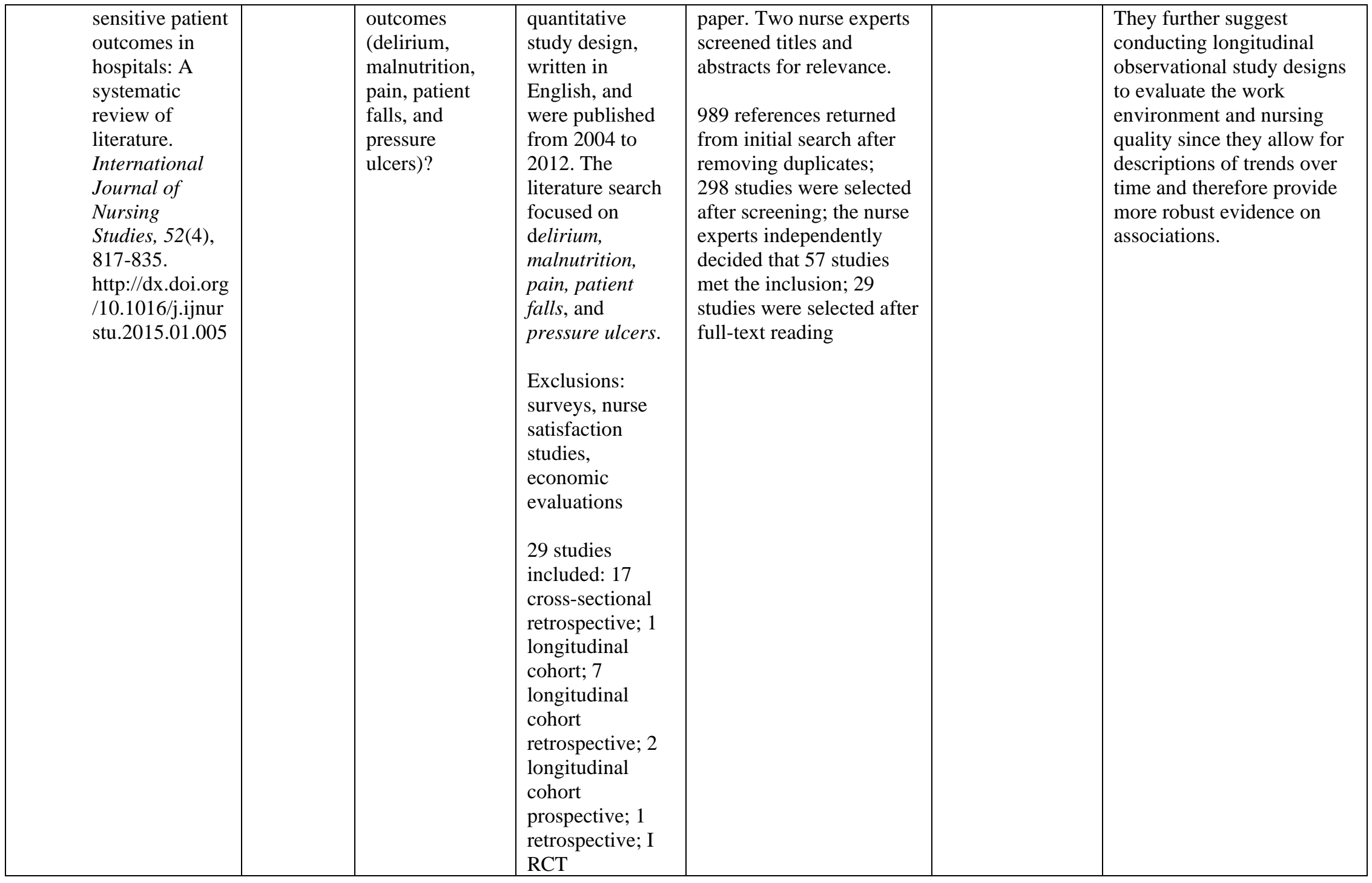

Legend:

RCT - Randomized Controlled Trial 


\section{Appendix C}

Timeline

\begin{tabular}{|c|c|c|c|}
\hline Task & Assigned To & Start & No. Days \\
\hline \multicolumn{4}{|c|}{ Practicum I (1/13/20 - 4/24/20) } \\
\hline Prepare Project Plan & & $1 / 13 / 2020$ & 90 \\
\hline \multicolumn{4}{|c|}{ Practicum II (5/11/20 - 8/14/20) } \\
\hline Submit Project Proposal for Approval & Hermes Vargas, Project Mgr. & $5 / 18 / 2020$ & 7 \\
\hline Assemble Project Team & Hermes Vargas, Project Mgr. & $5 / 25 / 2020$ & 14 \\
\hline In-Service 4N Staff and Nursing Supervisor & Medical/Surgical Nurse Educator & $5 / 25 / 2020$ & 14 \\
\hline Implement Project in Selected Unit & Nurse Manager \& Project Mgr. & June/2020 & 1 \\
\hline Collect Daily Fall \& Rounding Data & Charge Nurse & June/2020 & 60 \\
\hline Collect Daily \# Fall Risk Assessments Completed & Charge Nurse & June/2020 & 60 \\
\hline Collect Daily NHPPD Data & Nursing Supervisor & June/2020 & 60 \\
\hline Collect Daily Census Data & Nursing Supervisor & June/2020 & 60 \\
\hline Collect Daily Number of Sitters & Nursing Supervisor & June/2020 & 60 \\
\hline Evaluate Daily Project Progress/Status & Nurse Manager \& Project Mgr. & June/2020 & 60 \\
\hline Report Collected Data at Weekly Meetings & Nurse Manager \& Project Mgr. & June/2020 & 60 \\
\hline Conduct Weekly Meetings & Hermes Vargas, Project Mgr. & June/2020 & 60 \\
\hline Aggregate Data (Weekly) & Hermes Vargas, Project Mgr. & June/2020 & 60 \\
\hline Report Monthly Fall Data to Project Manager & Chair, Falls Prevention Committee & June/2020 & 60 \\
\hline \multicolumn{4}{|c|}{ Practicum III (9/7/20 - 12/18/20) \& Post DNP Program Completion } \\
\hline Analyze Project Data (Excel Data Analysis) & Hermes Vargas, Project Mgr. & $9 / 7 / 2020$ & 14 \\
\hline Report Findings to Unit/Service Leadership & Hermes Vargas, Project Mgr. & $9 / 22 / 2020$ & 1 \\
\hline $\begin{array}{l}\text { Report Findings to Patient Care Executive } \\
\text { Board (PCEB) (Note: Postponed until } \\
\text { December) }\end{array}$ & Hermes Vargas, Project Mgr. & $9 / 24 / 2020$ & 1 \\
\hline Celebrate Success & Project Team & $10 / 6 / 2020$ & 14 \\
\hline $\begin{array}{l}\text { Report Findings to the Falls Prevention } \\
\text { Committee }\end{array}$ & Hermes Vargas, Project Mgr. & $10 / 22 / 2020$ & 1 \\
\hline Submit to SOAR@USA & Hermes Vargas, Project Mgr. & $11 / 30 / 2020$ & 1 \\
\hline Report Findings to PCEB & Hermes Vargas, Project Mgr. & $12 / 23 / 2020$ & 1 \\
\hline Discuss Organization-Wide Dissemination & Chair, Falls Prevention Committee & $12 / 23 / 2020$ & 1 \\
\hline Present at VISN Process Improvement Forum & Hermes Vargas, Project Mgr. & $1 / 15 / 2021$ & 1 \\
\hline Submit for Publication & Hermes Vargas, Project Mgr. & $1 / 15 / 2021$ & $180-365$ \\
\hline
\end{tabular}




\section{Appendix D}

Budget

\begin{tabular}{|c|c|c|c|}
\hline Budget Line Item & Cost Unit & Average Cost & Total Cost \\
\hline 40 (Unit Staff) & 1 hour & $\$ 30.00$ & $\$ 1,200.00$ \\
\hline 10 (Operations Staff) & 1 hour & $\$ 45.00$ & $\$ 450.00$ \\
\hline Poster Preparation & 5-6 hours & $\$ 300-\$ 480$ & $\$ 300-\$ 480$ \\
\hline
\end{tabular}


Appendix E

Data Collection Tools

\begin{tabular}{|c|c|c|c|c|c|c|c|c|c|c|c|c|c|c|c|c|c|c|}
\hline Unit & $\begin{array}{c}\text { Bed } \\
\text { Capacity }\end{array}$ & Census & Arail Beds & Boarders & HPPD & $\begin{array}{c}\text { HPPD } \\
\text { Variance }\end{array}$ & \begin{tabular}{|c|} 
Boarder \\
Adj HPPD \\
Benchmar
\end{tabular} & \begin{tabular}{|c|} 
Adjusted \\
HPPD \\
Variance \\
\end{tabular} & Tour & $1: 1$ & RN/LPN & $\begin{array}{c}\text { RN/LPN } \\
\text { OT }\end{array}$ & $\mathrm{NA}$ & FALLS & Charge & \begin{tabular}{|c|} 
Staffing \\
Interventio \\
ns/Recore \\
\end{tabular} & 1:1 NA & $\begin{array}{l}1: 1 \mathrm{NA} \\
\text { OT }\end{array}$ \\
\hline \multirow{6}{*}{$\begin{array}{c}\text { Unit/Phone } \\
\text { Ext; NM } \\
\text { Ext: XXXX } \\
\text { Mobile: } \\
\text { 813-rxx- } \\
\text { xxxx }\end{array}$} & \multirow{6}{*}{27} & & 27 & & \#DIV/0! & \#DIV/0! & $=\mathrm{DIV} / 0 !$ & \#DIV/0! & $|0730-1200|$ & & & & & & & & & \\
\hline & & & 27 & & \#DIV/0! & \#DIV/0! & \#DIV/0! & \#DIV/0! & $1200-1600$ & & & & & & & & & \\
\hline & & & 27 & & \#DIV/0! & \#DIV/0! & \#DIV/0! & \#DIV/0! & $1600-2000$ & & & & & & & & & \\
\hline & & & 27 & & \#DIV/0! & \#DIV/0! & \#DIV/0! & \#DIV/0! & $2000-2400$ & & & & & & & & & \\
\hline & & & 27 & & \#DIV/0! & \#DIV/0! & \#DIV/0! & \#DIV/0! & $2400-0400$ & & & & & & & & & \\
\hline & & & 27 & & \#DIV/0! & \#DIV/0! & \#DIV/0! & \#DIV/0! & $|0400-0800|$ & & & & & & & & & \\
\hline
\end{tabular}

Patient Falls Data

\begin{tabular}{|l|l|l|l|l|}
\hline Patient ID & Room \# & Age & Gender & Morse Fall Risk Level \\
\hline & & & & \\
\hline & & & & \\
\hline & & & & \\
\hline & & & & \\
\hline
\end{tabular}

\begin{tabular}{|l|l|l|l|}
\hline Unit & Month & $1600-2000$ Fall Rate & All Shifts Fall Rate \\
\hline & & & \\
\hline & & & \\
\hline & & & \\
\hline & & & \\
\hline & & & \\
\hline
\end{tabular}


Appendix F

Data Collection Plan

\begin{tabular}{|c|c|c|c|}
\hline Type of Data & Responsible Party & Frequency & Comments \\
\hline Census & $\begin{array}{l}\text { Nurse Manager updates } \\
\text { AcuStaf }\end{array}$ & Daily & $\begin{array}{l}\text { Ongoing correction by Nursing } \\
\text { Supervisor }\end{array}$ \\
\hline & Nurse Manager updates & & Ongoing correction by Nursing \\
\hline Staffing & AcuStaf & Daily & Supervisor \\
\hline NHPPD & Nursing Supervisor & $\begin{array}{l}\text { Calculated } \\
\text { every } 4 \text { hours }\end{array}$ & $\begin{array}{l}\text { Nursing supervisor reports cross- } \\
\text { referenced with Pyramid } \\
\text { Analytics report }\end{array}$ \\
\hline $\begin{array}{l}\text { Hourly } \\
\text { Rounding } \\
\text { Compliance }\end{array}$ & $\begin{array}{l}\text { Charge Nurse/Nurse } \\
\text { Manager }\end{array}$ & Every hour & $\begin{array}{l}\text { Reviewed daily by Nurse } \\
\text { Manager. Cross-referenced with } \\
\text { Pyramid Analytics report }\end{array}$ \\
\hline Number of Falls & $\begin{array}{l}\text { Charge Nurse / Nursing } \\
\text { Supervisor }\end{array}$ & Daily & $\begin{array}{l}\text { Reported by Charge Nurse and } \\
\text { Validated by Nursing Supervisor }\end{array}$ \\
\hline Fall Rate & $\begin{array}{l}\text { Falls Prevention } \\
\text { Committee }\end{array}$ & Monthly & $\begin{array}{l}\text { Obtained from Patient Safety } \\
\text { reports cross-referenced with } \\
\text { Nursing Supervisor reports }\end{array}$ \\
\hline
\end{tabular}




\section{Appendix G}

Process, Measures, and Outcomes

\begin{tabular}{|c|c|c|}
\hline Measure & Type of Measure & Expected Outcome \\
\hline Decrease Fall Rate & Outcome & $\begin{array}{l}\text { Decrease from } 3.76 / 1000 \text { bed } \\
\text { days to } \leq 3.40 / 1000 \text { bed days }\end{array}$ \\
\hline Increase Hourly Rounds & Process & Increase from $70 \%$ to $\geq 90 \%$ \\
\hline $\begin{array}{l}\text { Increase Percentage of Post-Fall Huddles } \\
\text { Increase Percentage of Fall-Risk } \\
\text { Reassessments }\end{array}$ & $\begin{array}{l}\text { Process } \\
\text { Process }\end{array}$ & $\begin{array}{l}\text { Increase from } 75 \% \text { to } \geq 90 \% \\
\text { Increase from } 75 \% \text { to } \geq 90 \%\end{array}$ \\
\hline $\begin{array}{l}\text { Increase Percentage of High Fall Risk } \\
\text { Patients with Documented Falls Prevention } \\
\text { Plan }\end{array}$ & Process & Increase from $80 \%$ to $\geq 90 \%$ \\
\hline NHPPD & Balancing & $\begin{array}{l}\text { Maintain within } \pm 10 \% \text { of the } \\
\text { benchmark }\end{array}$ \\
\hline Patient Satisfaction & Balancing & Increase score from 8.1 to $\geq 9.0$ \\
\hline
\end{tabular}


Appendix $\mathrm{H}$

\begin{tabular}{|c|c|c|c|c|c|c|}
\hline & Variable & Description & $\begin{array}{l}\text { Data } \\
\text { Source }\end{array}$ & $\begin{array}{l}\text { Possible } \\
\text { Range of } \\
\text { Values } \\
\end{array}$ & $\begin{array}{c}\text { Level of } \\
\text { Measurement }\end{array}$ & $\begin{array}{c}\text { Time } \\
\text { Frame for } \\
\text { Collection } \\
\end{array}$ \\
\hline \multirow{3}{*}{ Population } & Age & $\begin{array}{l}\text { Patient age } \\
\text { at the time } \\
\text { of fall }\end{array}$ & \multirow{3}{*}{$\begin{array}{c}\text { Electronic } \\
\text { Health } \\
\text { Record }\end{array}$} & $25-110$ & Ratio & $\begin{array}{l}\text { At the } \\
\text { time of } \\
\text { reported } \\
\text { fall }\end{array}$ \\
\hline & Gender & $\begin{array}{l}\text { Patient } \\
\text { gender } \\
\text { values } \\
\text { currently } \\
\text { captured in } \\
\text { the } \\
\text { admission } \\
\text { program }\end{array}$ & & $\begin{array}{l}2=\text { Female } \\
1=\text { Male } \\
0= \\
\text { Transgender }\end{array}$ & Nominal & $\begin{array}{l}\text { At the } \\
\text { time of } \\
\text { reported } \\
\text { fall }\end{array}$ \\
\hline & $\begin{array}{l}\text { Morse } \\
\text { Fall Risk }\end{array}$ & $\begin{array}{l}\text { Fall risk } \\
\text { level based } \\
\text { on validated } \\
\text { Morse Falls } \\
\text { Scale Tool }\end{array}$ & & $\begin{array}{l}0=\text { Low } \\
\text { Risk } \\
1= \\
\text { Moderate } \\
\text { Risk } \\
2=\text { High } \\
\text { Risk } \\
\end{array}$ & Ordinal & $\begin{array}{l}\text { At the } \\
\text { time of } \\
\text { reported } \\
\text { fall }\end{array}$ \\
\hline \multirow[b]{2}{*}{ Event } & Census & $\begin{array}{l}\text { Number of } \\
\text { patients } \\
\text { admitted in } \\
\text { the unit }\end{array}$ & \multirow[b]{2}{*}{$\begin{array}{l}\text { AcuStaf } \\
\text { Staffing } \\
\text { Program }\end{array}$} & $1-21$ & Ratio & $\begin{array}{l}\text { At the } \\
\text { time of } \\
\text { reported } \\
\text { fall }\end{array}$ \\
\hline & $\begin{array}{l}\text { Number } \\
\text { of Direct } \\
\text { Care } \\
\text { Nursing } \\
\text { Staff }\end{array}$ & $\begin{array}{l}\text { Number of } \\
\text { Registered } \\
\text { Nurses } \\
\text { (RN) and } \\
\text { Nursing } \\
\text { Assistants } \\
\text { (NA) at } \\
\text { time of fall } \\
\text { (Note: The } \\
\text { Acute Care } \\
\text { Nursing } \\
\text { Service } \\
\text { only } \\
\text { employs } \\
\text { RNs and } \\
\text { NAs) }\end{array}$ & & $1-10$ & Ratio & $\begin{array}{l}\text { At the } \\
\text { time of } \\
\text { reported } \\
\text { fall }\end{array}$ \\
\hline
\end{tabular}




\begin{tabular}{|c|c|c|c|c|c|c|}
\hline & $\begin{array}{l}\text { Time } \\
\text { Period }\end{array}$ & $\begin{array}{l}\text { Time } \\
\text { interval } \\
\text { when } \\
\text { patient fall } \\
\text { occurred }\end{array}$ & $\begin{array}{l}\text { Patient } \\
\text { Safety } \\
\text { Report }\end{array}$ & $\begin{array}{l}0=0000- \\
0400 \\
1=0401- \\
0800 \\
2=0801- \\
1200 \\
3=1201- \\
1600 \\
4=1601- \\
2000 \\
5=2001- \\
2400\end{array}$ & Interval & $\begin{array}{l}\text { At the } \\
\text { time of } \\
\text { reported } \\
\text { fall }\end{array}$ \\
\hline Outcome & $\begin{array}{l}\text { Reduced } \\
\text { Fall Rate }\end{array}$ & $\begin{array}{l}\text { The fall rate } \\
\text { is calculated } \\
\text { By the } \\
\text { number of } \\
\text { falls divided } \\
\text { by the } \\
\text { number of } \\
\text { occupied } \\
\text { bed days for } \\
\text { the month } \\
\text { multiplied } \\
\text { by } 1000\end{array}$ & $\begin{array}{c}\text { Patient } \\
\text { Safety } \\
\text { Reports } \\
\text { and } \\
\text { Acustaf } \\
\text { Reports }\end{array}$ & $0-21$ & Ratio & $\begin{array}{l}\text { Every } \\
\text { month }\end{array}$ \\
\hline
\end{tabular}




\section{Appendix I}

\begin{tabular}{|c|c|c|c|c|c|c|c|c|c|}
\hline $\begin{array}{l}\text { Date - } \\
\text { FY'20 }\end{array}$ & $\begin{array}{l}\text { Day of } \\
\text { Week }\end{array}$ & $\begin{array}{c}\text { HPPD } \\
\text { Benchmark @ } \\
1600-2000\end{array}$ & $\begin{array}{l}\text { Actual } \\
\text { HPPD }\end{array}$ & Census & $\begin{array}{c}\text { Occupancy Rate } \\
1600-2000\end{array}$ & Special Obs & Falls & $\begin{array}{c}1600- \\
2000 \text { Fall } \\
\text { Rate }\end{array}$ & $\begin{array}{c}\text { All Shifts Fall } \\
\text { Rate }\end{array}$ \\
\hline 8-Jun & $M$ & 1.55 & 1.68 & 20 & $74 \%$ & 2 & 0 & & \\
\hline 9-Jun & $\mathrm{T}$ & 1.55 & 1.77 & 19 & $70 \%$ & 2 & 0 & & \\
\hline 10-Jun & W & 1.55 & 1.81 & 19 & $70 \%$ & 3 & 0 & & \\
\hline 11-Jun & $\mathrm{TH}$ & 1.55 & 1.75 & 21 & $78 \%$ & 1 & 0 & & \\
\hline 12-Jun & $\mathrm{F}$ & 1.55 & 1.60 & 21 & $78 \%$ & 2 & 0 & & \\
\hline 13-Jun & $S$ & 1.55 & 2.44 & 18 & $67 \%$ & 0 & 0 & & \\
\hline 14-Jun & $\mathrm{Su}$ & 1.55 & 2.25 & 16 & $59 \%$ & 1 & 0 & & \\
\hline 15-Jun & $M$ & 1.55 & 1.82 & 22 & $81 \%$ & 0 & 0 & & \\
\hline 16-Jun & $\mathrm{T}$ & 1.55 & 1.89 & 19 & $70 \%$ & 0 & 0 & & \\
\hline 17-Jun & W & 1.55 & 1.78 & 18 & $67 \%$ & 0 & 0 & & \\
\hline 18-Jun & $\mathrm{TH}$ & 1.55 & 1.56 & 21 & $78 \%$ & 0 & 0 & & \\
\hline 19-Jun & $\mathrm{F}$ & 1.55 & 1.73 & 19 & $70 \%$ & 1 & 0 & & \\
\hline 20-Jun & $S$ & 1.55 & 2.45 & 15 & $56 \%$ & 0 & 0 & & \\
\hline 21-Jun & Su & 1.55 & 2.45 & 15 & $56 \%$ & 1 & 1 & & \\
\hline 22-Jun & $M$ & 1.55 & 1.69 & 17 & $63 \%$ & 1 & 0 & & \\
\hline 23-Jun & $\mathrm{T}$ & 1.55 & 1.81 & 19 & $70 \%$ & 2 & 0 & & \\
\hline 24-Jun & W & 1.55 & 1.9 & 16 & $59 \%$ & 2 & 0 & & \\
\hline 25-Jun & $\mathrm{TH}$ & 1.55 & 1.64 & 20 & $74 \%$ & 1 & 0 & & \\
\hline 26-Jun & $\mathrm{F}$ & 1.55 & 1.83 & 18 & $67 \%$ & 1 & 0 & & \\
\hline 27-Jun & $S$ & 1.55 & 2.89 & 13 & $48 \%$ & 1 & 0 & & \\
\hline 28-Jun & $\mathrm{Su}$ & 1.55 & 2.58 & 13 & $48 \%$ & 2 & 0 & & \\
\hline 29-Jun & $M$ & 1.55 & 2.73 & 12 & $44 \%$ & 1 & 0 & & \\
\hline 30-Jun & $\mathrm{T}$ & 1.55 & 2.16 & 17 & $63 \%$ & 1 & 0 & & \\
\hline EOM-June & & & 2.01 & 408 & $66 \%$ & 1.09 & 1 & 0 & 2.45 \\
\hline 1-Jul & W & 1.55 & 1.82 & 18 & $67 \%$ & 1 & 0 & & \\
\hline 2-Jul & $\mathrm{TH}$ & 1.55 & 1.73 & 19 & $70 \%$ & 1 & 0 & & \\
\hline 3-Jul & $\mathrm{F}$ & 1.55 & 2.3 & 16 & $59 \%$ & 1 & 0 & & \\
\hline 4-Jul & $S$ & 1.55 & 1.74 & 17 & $63 \%$ & 2 & 0 & & \\
\hline 5-Jul & Su & 1.55 & 1.79 & 17 & $63 \%$ & 3 & 0 & & \\
\hline 6-Jul & $M$ & 1.55 & 1.64 & 18 & $67 \%$ & 2 & 0 & & \\
\hline 7-Jul & $\mathrm{T}$ & 1.55 & 1.53 & 22 & $81 \%$ & 2 & 0 & & \\
\hline 8-Jul & W & 1.55 & 1.46 & 23 & $85 \%$ & 2 & 0 & & \\
\hline 9-Jul & TH & 1.55 & 1.39 & 27 & $100 \%$ & 3 & 1 & & \\
\hline 10-Jul & $\mathrm{F}$ & 1.55 & 1.31 & 25 & $93 \%$ & 1 & 0 & & \\
\hline 11-Jul & $S$ & 1.55 & 1.88 & 20 & $74 \%$ & 2 & 0 & & \\
\hline 12-Jul & Su & 1.55 & 2.09 & 18 & $67 \%$ & 2 & 0 & & \\
\hline 13-Jul & $M$ & 1.55 & 1.38 & 22 & $81 \%$ & 3 & 0 & & \\
\hline 14-Jul & $\mathrm{T}$ & 1.55 & 1.5 & 25 & $93 \%$ & 2 & 0 & & \\
\hline 15-Jul & W & 1.55 & 1.43 & 23 & $85 \%$ & 2 & 0 & & \\
\hline 16-Jul & $\mathrm{TH}$ & 1.55 & 1.42 & 22 & $88 \%$ & 5 & 0 & & \\
\hline 17-Jul & $\mathrm{F}$ & 1.55 & 1.3 & 24 & $89 \%$ & 5 & 0 & & \\
\hline 18-Jul & $S$ & 1.55 & 2.09 & 15 & $56 \%$ & 4 & 0 & & \\
\hline 19-Jul & Su & 1.55 & 1.95 & 16 & $59 \%$ & 4 & 0 & & \\
\hline 20-Jul & $M$ & 1.55 & 1.54 & 25 & $93 \%$ & 3 & 1 & & \\
\hline 21-Jul & $\mathrm{T}$ & 1.55 & 1.57 & 22 & $81 \%$ & 3 & 0 & & \\
\hline 22-Jul & W & 1.55 & 1.25 & 27 & $100 \%$ & 4 & 0 & & \\
\hline 23-Jul & TH & 1.55 & 1.31 & 27 & $100 \%$ & 4 & 1 & & \\
\hline 24-Jul & $\mathrm{F}$ & 1.55 & 1.88 & 20 & $74 \%$ & 2 & 0 & & \\
\hline 25-Jul & $S$ & 1.55 & 1.56 & 21 & $78 \%$ & 1 & 0 & & \\
\hline 26-Jul & $\mathrm{Su}$ & 1.55 & 1.49 & 22 & $81 \%$ & 1 & 0 & & \\
\hline 27-Jul & $M$ & 1.55 & 1.31 & 25 & $93 \%$ & 1 & 0 & & \\
\hline 28-Jul & $\mathrm{T}$ & 1.55 & 1.57 & 26 & $96 \%$ & 1 & 0 & & \\
\hline 29-Jul & W & 1.55 & 1.89 & 19 & $70 \%$ & 2 & 0 & & \\
\hline 30-Jul & $\mathrm{TH}$ & 1.55 & 1.4 & 24 & $89 \%$ & 2 & 0 & & \\
\hline 31-Jul & $\mathrm{F}$ & 1.55 & 1.46 & 23 & $85 \%$ & 2 & 0 & & \\
\hline EOM - July & & & 1.61 & 668 & $80 \%$ & 2.4 & 3 & 0 & 4.49 \\
\hline 1-Aug & $S$ & 1.55 & 1.88 & 20 & $74 \%$ & 3 & 1 & & \\
\hline 2-Aug & $\mathrm{Su}$ & 1.55 & 1.64 & 21 & $78 \%$ & 3 & & & \\
\hline \multicolumn{3}{|c|}{ Cummulative Calculations } & 1.78 & 1117 & $74 \%$ & 1.9 & 5 & 0 & 4.48 \\
\hline
\end{tabular}

